\title{
Using Polymeric Materials to Control Stem Cell Behavior for Tissue Regeneration
}

\author{
Nianli Zhang and David H. Kohn*
}

Patients with organ failure often suffer from increased morbidity and decreased quality of life. Current strategies of treating organ failure have limitations, including shortage of donor organs, low efficiency of grafts, and immunological problems. Tissue engineering emerged about two decades ago as a strategy to restore organ function with a living, functional engineered substitute. However, the ability to engineer a functional organ is limited by a limited understanding of the interactions between materials and cells that are required to yield functional tissue equivalents. Polymeric materials are one of the most promising classes of materials for use in tissue engineering, due to their biodegradability, flexibility in processing and property design, and the potential to use polymer properties to control cell function. Stem cells offer potential in tissue engineering because of their unique capacity to self-renew and differentiate into neurogenic, osteogenic, chondrogenic, and myogenic lineages under appropriate stimuli from extracellular components. This review examines recent advances in stem cell-polymer interactions for tissue regeneration, specifically highlighting control of polymer properties to direct adhesion, proliferation, and differentiation of stem cells, and how biomaterials can be designed to provide some of the stimuli to cells that the natural extracellular matrix does. Birth Defects Research (Part C) 96:6381, 2012. $\odot 2012$ Wiley Periodicals, Inc.

Key words: stem cells; polymer; tissue engineering; adhesion; proliferation; differentiation

\section{INTRODUCTION}

Failure of organ function due to injury, disease, or aging accounts for a significant number of clinical disorders at a tremendous social and economic cost (Freed et al., 2009). In the United States, nearly 6 million bone fractures occur each year (Zhao et al., 2010), and worldwide, 8 million persons suffer a myocardial infarction (Kraehenbuehl et al., 2008). The failure of organs also has a significant impact on quality of life. For example, patients with traumatic spinal cord injury often suffer lifetime sensory and motor deficits below the site of injury (Hsieh et al., 2010).

Current treatments for organ failure vary with the type of organ affected, but all have limitations. For cardiac functional failure, one of the current strategies is to deliver functional cells to the myocardium. However, this strategy results in low engraftment efficiency and cell viability in infracted hearts (Ye et al., 2011). Cardiac transplantation can significantly lengthen and improve quality of life. It is limited, however, due to a chronic shortage of donor hearts (Leor et al., 2000). With the replacement of diseased or damaged bone, autologous bone grafts are preferable because they contain the patient's own cells and proteins, which not only provide a framework for new bone to grow into, but also are immunogenetically compatible. Despite satisfying clinical results, autografts often lead to morbidity at the surgical site. Another strategy is to use an allogenic bone graft. However, utilization of these grafts carries the risk of immunological rejection or disease transfer (Cordonnier et al., 2011).

To overcome these limitations in organ transplantation and grafting, the field of tissue engineering emerged about two decades ago. Tissue engineering combines the disciplines of both the materials sciences and the life sciences to replace a diseased or damaged tissue or organ with a living, functional engineered substitute (Chan and Mooney, 2008; Marklein and Burdick, 2010). However, tissues such as bone, articular cartilage, and myocardium possess highly specialized structures and compositions that provide unique mechanical and transport properties (Freed et al., 2009). Therefore, to reconstruct a functional engineered tissue substitute, it is necessary to understand how these specialized structures and compositions affect cell behavior in vivo, and use this information to direct the design of substitute tissues and organs. Unfortunately, our ability to design

\footnotetext{
Nianli Zhang and David H. Kohn are from The Department of Biologic and Materials Sciences, University of Michigan, Ann Arbor, Michigan 48109-1078

David H. Kohn is also from The Department of Biomedical Engineering, University of Michigan, Ann Arbor, Michigan 48109-2099

*Correspondence to: David H. Kohn, Department of Biologic and Materials Sciences, University of Michigan, Ann Arbor, Michigan 48109-1078. E-mail: dhkohn@umich.edu

View this article online at (wileyonlinelibrary.com). DOI: $10.1002 /$ bdrc.21003
} 
a functional organ substitute is limited by an incomplete understanding of the interactions between materials and cells, and an inability to control the complex signaling pathways elicited by these interactions (Fisher et al., 2010).

The first question that needs to be answered, to optimize any tissue engineering strategy geared toward producing a functional tissue equivalent, is what cell type and substrate material are appropriate for the particular tissue engineering goal at hand. Stem cells and polymeric materials are key design choices due to their unique properties. Briefly, stem cells have the ability to self-renew and commit to specific cell lineages under appropriate stimuli. Polymeric materials are biocompatible, degradable, and flexible in processing and property design. A significant focus of tissue engineering, therefore, is to utilize polymers, or soft materials, as a means of controlling stem cell function via physical, chemical, mechanical, and/or biological cues "communicated" to from the polymer to the cells.

This review examines recent progress in stem cell-polymer interactions for tissue regeneration. Specifically, we focus on how polymer material properties affect the activity of stem cells in vitro and further tissue regeneration in vivo. The design of novel polymeric biomaterials with appropriate physical, chemical, mechanical, and biological cues to guide stem cell adhesion, proliferation, and differentiation are discussed. Finally, we discuss how the ability of a biomaterial to guide stem cell function can lead to improved outcomes for nerve, bone, cartilage, and cardiac regeneration.

\section{Characteristics of Stem Cells}

Stem cells are an important cell type for cell-based therapy and regenerative medicine, especially within the rapidly expanding field of tissue engineering, due to their two unique properties, selfrenewal and differentiation. With the first unique property, these cells can be easily expanded in vitro and, therefore, a large cell number can be obtained for seeding onto three-dimensional (3D) scaffolds of clinically relevant volume and subsequent cell transplantation. Stem cells can also give rise to more committed cell types, such as osteoblasts, chondrocytes, adipocytes, and neuronal cells, when they receive the appropriate cues.

Based on their differentiation potential, stem cells used for tissue engineering can be divided into two categories, pluripotent stem cells and multipotent stem cells. Pluripotent stem cells include embryonic stem cells (ESC) and induced pluripotent stem cells (iPSC). Compared to multipotent stem cells, pluripotent cells can self-renew indefinitely. Their pluripotent nature gives them the ability to differentiate into any one of the three germ layers: endoderm, ectoderm, and mesoderm (Dawson et al., 2008). Because ESCs are isolated from the inner cell mass of the blastocyst during embryological development, their use in tissue engineering is controversial and more limited. Although iPSCs are obtained by genetically modifying somatic cells, more attention has been paid to this cell type recently. Examples of multipotent stem cells include bone marrow derived-mesenchymal stem cells (MSCs), hematopoietic stem cells, neural stem cells (NSCs), and adipose derived stem cells (ASCs). These stem cells exist in the corresponding differentiated tissues, renew themselves for the lifetime of the organism, and yield all of the specialized cell types of the tissue from which they are originated.

\section{Factors Controlling Stem Cell Behavior}

Maintaining stem cells in an undifferentiated state and subsequently directing them to differentiate in a reliable and reproducible manner into specific cell types are key issues in stem cell biology (Dawson et al., 2008) and consequently in stem cell-based tissue engineering. Cell adhesion, proliferation, and differentiation are largely dictated by signals from extracellular components, such as soluble biological and pharmacological factors in fluid, extracellular matrix (ECM), and other adjacent cells (cell-cell crosstalk; Fig. 1). It has been long recognized that not only the type, but also the dose, spatial and temporal distribution of soluble factors play an important role in mediating cell behavior (Luong et al., 2006; Beohar et al., 2010; Zhang et al., 2010b). Various properties of the ECM influence cell adhesion, proliferation, and differentiation, including physical properties (roughness, stiffness, surface patterning, and electrical conductivity), chemical properties (concentration of monomers and functional groups), as well as structural properties (crosslinking, morphology, 2D vs. 3D) (Murphy et al., 2005). Cell-cell communication is also critical to cell differentiation. For example, enhancement of gap junction intercellular communication leads to an increased magnitude and spatial distribution of differentiation markers and consequently an increased volume fraction and spatial uniformity of in vivo (Rossello et al., 2009). Individual factors, as well as combinations of factors from the extracellular environment, affect cell adhesion, viability, proliferation, and differentiation (Chan and Mooney, 2008; Dawson et al., 2008). Therefore, a key to advancing tissue engineering is the ability to control the signaling of multiple factors simultaneously.

\section{Polymeric Materials for Tissue Repair and Regeneration}

Polymeric materials for tissue regeneration are of both natural and synthetic origin (Table 1 ). Examples of natural polymers include collagen, fibrin, and polysaccharides, such as hyaluronic acid and alginate. Natural polymers contain a variety of biological cues, including cell adhesion sequences, and therefore, can be recognized by cells. However, natural polymers are subjected to batch-to-batch variation due to the complexity of 


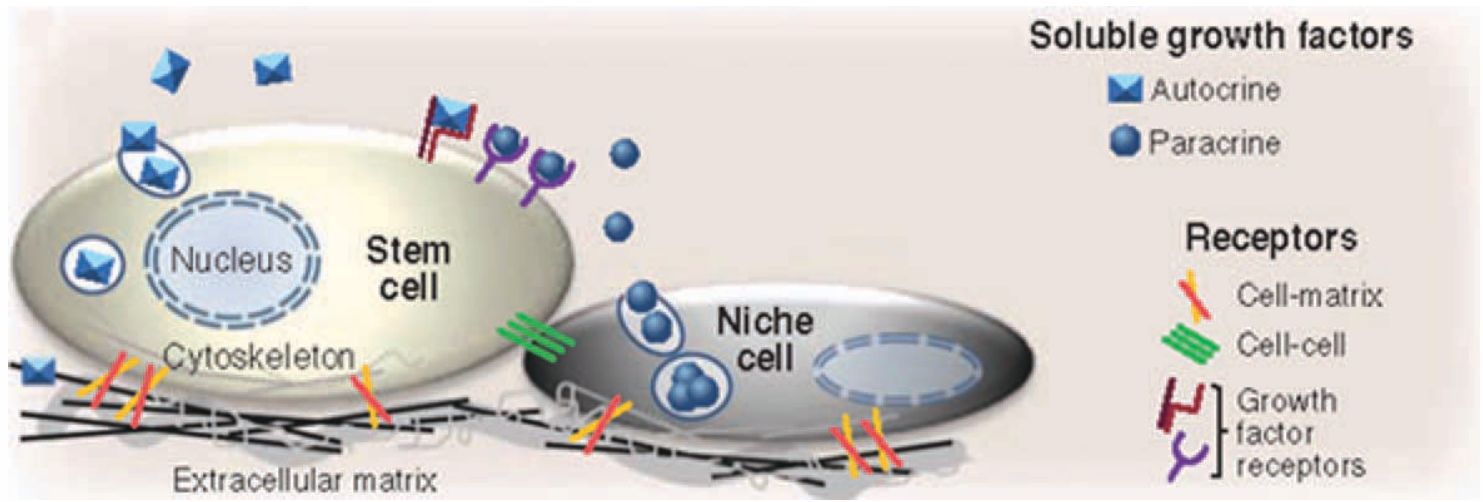

Figure 1. Factors controlling stem cell behavior arise from their interactions with growth factors, ECM, and niche cells (Schematic diagram is modified from "D. E. Discher, et al. (2009). Growth factors, matrices, and forces combine and control stem cells. Science 324, 1673"; copyright 2009, with permission from The American Association for the Advancement of Science).

their structure and chemical composition, leading to variations in tissue engineering outcomes. Compared to natural polymers, synthetic polymers can be more easily synthesized on a large scale with more precisely controlled molecular weight and addition of functional groups. However, synthetic polymers in their native state can only support cell adhesion and growth to a limited extent since they lack functional groups for cell interaction (Alvarez-Barreto et al., 2011). The synthetic polymers that have

\begin{tabular}{|c|c|c|}
\hline Polymer name & Main applications and properties & References \\
\hline \multicolumn{3}{|l|}{ Natural polymers } \\
\hline Alginate & $\begin{array}{l}\text { Bone, nerve, and cartilage regeneration; } \\
\text { enzymatically degradable }\end{array}$ & $\begin{array}{l}\text { Banerjee et al. (2009), } \\
\text { Shanbhag } \\
\text { et al. (2010) }\end{array}$ \\
\hline Collagen & $\begin{array}{l}\text { Bone, heart and cartilage regeneration; } \\
\text { enzymatically degradable }\end{array}$ & Battista et al. (2005) \\
\hline Hyaluronic acid & $\begin{array}{l}\text { Cartilage, nerve regeneration; } \\
\text { degradable }\end{array}$ & $\begin{array}{l}\text { Tian et al. (2005), Ren } \\
\text { et al., (2009), Park } \\
\text { et al. (2010) }\end{array}$ \\
\hline Chitosan & Cartilage regeneration; degradable & Chung et al. (2011) \\
\hline Fibrin & $\begin{array}{l}\text { Cartilage regeneration; degradable, } \\
\text { injectable }\end{array}$ & Ahearne et al. (2011) \\
\hline \multicolumn{3}{|l|}{ Synthetic polymers } \\
\hline Poly(vinyl alcohol) & Cartilage regeneration; nondegradable & Spiller et al. (2011) \\
\hline Poly(hydroxyethyl methacrylate) & Cartilage regeneration; nondegradable & Singh et al. (2011) \\
\hline Poly(N-isopropylacrylamide) & Cartilage regeneration; nondegradable & Sa-Lima et al. (2011) \\
\hline Polyethylene terephthalate & Bone regeneration; nondegradable & Cao et al. (2010) \\
\hline PGA & Cartilage regeneration; bulk degradable & Bilir et al. (2011) \\
\hline Poly(lactic acid) PLA & $\begin{array}{l}\text { Cartilage, nerve, bone regeneration; } \\
\text { degradable }\end{array}$ & $\begin{array}{l}\text { Yang et al. (2005) } \\
\text { Liao et al. (2011) }\end{array}$ \\
\hline Polyethylene oxide & $\begin{array}{l}\text { Cartilage regeneration; injectable, } \\
\text { degradable }\end{array}$ & Akpalo et al. (2011) \\
\hline PLGA & $\begin{array}{l}\text { Bone, nerve regeneration; bulk } \\
\text { degradable }\end{array}$ & Levenberg et al. (2003) \\
\hline Poly caprolactone & Bone, nerve regeneration; degradable & Mahairaki et al. (2011) \\
\hline Polypyrrole (PPy) & Nerve regeneration; conductive polymer & Lundin et al. (2011) \\
\hline Poly (propylene fumarte) & $\begin{array}{l}\text { Bone regeneration; bulk degradable, } \\
\text { injectable }\end{array}$ & Shin et al. (2011) \\
\hline Polyanhydrides & Bone regeneration, surface degradable & Li et al. (2004) \\
\hline Aminopropylmethacrylamide (APMAAm) & $\begin{array}{l}\text { Support self renewal of human } \\
\text { embryonic stem cell }\end{array}$ & Irwin et al. (2011) \\
\hline $\begin{array}{l}\text { Poly(methyl vinyl } \\
\text { ether-alt-maleic anhydride) }\end{array}$ & $\begin{array}{l}\text { Support self renewal of human } \\
\text { embryonic stem cell }\end{array}$ & Brafman et al. (2010) \\
\hline PEG & Heart, bone regeneration; degradable & $\begin{array}{l}\text { Kraehenbuehl et al. } \\
\text { (2008) }\end{array}$ \\
\hline
\end{tabular}


received the most study are poly (L-lactic acid) (PLLA), poly(glycolic acid) (PGA), poly(lactic-co-glycolic acid) (PLGA), poly(ethylene glycol) (PEG), polycaprolactones, polyorthoesters, polyanhydrides, and polycarbonates (Chan and Mooney, 2008).

There are at least two advantages of using polymeric materials for tissue regeneration. First, the structure and composition of polymers can be easily tailored to yield a variety of physical and chemical properties that can elicit certain cellular functions, including proliferation and differentiation in a controlled manner. Second, many of the polymers are biodegradable through either hydrolysis or via activities of enzymes secreted by cells. Therefore, over a prescribed time, the scaffold can be replaced by newly formed tissue. Thus, with degrading polymers, a secondary surgery is not needed to remove the scaffold after implantation.

A drawback of many polymers, however, is that their biocompatibility is lower than other types of biomaterials, such as ceramic materials. Polymeric materials are usually encapsulated by a persistent layer of fibroblasts, collagen, and inflammatory cells in vivo, which is suboptimal for tissue formation (Vergroesen et al., 2011). However, the biocompatibility of polymer materials can be improved by engineering functionality into these materials. The behavior of stem cells can be controlled by engineering functionality into a biomaterial, such as via immobilization of adhesion peptides, modification of surface chemistry, and mineralizing polymer surfaces.

\section{CELL ADHESION AND PROLIFERATION ON POLYMERIC MATERIALS \\ 2D Polymeric Substrates}

2D polymeric substrates have been used for in vitro cell culture for decades, and surface properties of roughness and topography can be more easily and precisely controlled over a 2D surface than a 3D scaffold (Naing and Williams, 2011). A well-defined surface can subsequently benefit the study of the interactions between cells and materials, decrease variability in cell response, and lead to less complication in the interpretation of data. Effects of surface properties, such as stiffness and topography, on cell adhesion and proliferation have been extensively investigated (Castellani et al., 1999; Discher et al., 2005; Saha et al., 2008).

The magnitude of surface stiffness affects cell adhesion and proliferation (Pek et al., 2010; Wang et al., 2010a; Chandler et al., 2011; Park et al., 2011a; Schrader et al., 2011). For example, 2D polymer substrates with moduli greater than $1000 \mathrm{~Pa}$ favor proliferation of adult NSCs, whereas cell spreading and proliferation are inhibited on substrata with moduli of $10 \mathrm{~Pa}$ (Saha et al., 2008). The trend of stiffer surfaces leading to a higher rate of proliferation holds for many other cell types, such as adipose progenitor cells, human MSCs, and hepatocellular carcinoma cells (Wang et al., 2010a; Chandler et al., 2011; Park et al., 2011a; Schrader et al., 2011).

Besides surface stiffness, surface topography is another important factor that controls cell adhesion and proliferation. Various fabrication methods are used to alter surface topography or create microscale and nanoscale features to facilitate cell adhesion (Castellani et al., 1999; Hatano et al., 1999; Deligianni et al., 2001; Anselme et al., 2002; Korovessis et al., 2002; Linez-Bataillon et al., 2002; Zhao et al., 2006b). Surfaces with lower periodicity (e.g., totally random surface) generally favor cell adhesion and proliferation (Anselme et al., 2000; Bigerelle and Iost, 2001). However, most studies only focus on cell responses to static surface topography or patterning. One interesting study designed a dynamic substrate that can communicate active physical cues to cells (Le et al., 2011). In this study, the surface of thermally responsive poly ( $\varepsilon$-caprolactone) shape-memory polymers transformed between a $3 \times 5 \mu \mathrm{m}^{2}$ channel array and a planar surface at $37^{\circ} \mathrm{C}$. Correspond- ingly, the morphology of hMSCs switched from highly aligned to stellate shaped. Meanwhile, cell attachment and detachment can be controlled by thermally responsive polymer substrates (Hatakeyama et al., 2005; Idota et al., 2009; Kumashiro et al., 2010). The detachment of cells from such temperature-responsive surfaces is achieved by lowering the temperature without conventional enzymatic treatment, while keeping the deposited ECM intact (Kumashiro et al., 2010).

Two-dimensional polymeric surfaces have been investigated for supporting self-renewal of pluripotent stem cells, including ESCs and iPSCs (Brafman et al., 2010; Villa-Diaz et al., 2010; Irwin et al., 2011). The successful integration of stem cells into tissue engineering requires large-scale cell expansion without differentiation. Therefore, the precise control the self-renewal of stem cells is important (Irwin et al., 2011).

The motivation for using a $2 \mathrm{D}$ polymeric substrate to support self-renewal of pluripotent stem cells is the lack of chemically defined culture system for these cells. Pluripotent stem cells are typically maintained on a feeder layer of mouse cells with a combination of the animal-based products, which are expensive, difficult to isolate, subject to batch-tobatch variations, and unsuitable for translation cell-based therapies to the clinic (Brafman et al., 2010). Therefore, a defined system is needed for better supporting hESC self-renewal. The first attempt to create a fully defined synthetic polymer coating to support hESC self-renewal was done by Villa-Diaz et al. (2010), where poly[2-(methacryloyloxy)ethyl dimethyl-(3-sulfopropyl)ammonium hydroxide] (PMEDSAH) was created by UV-ozone activated polymerization. Cells seeded on PMEDSAH expressed characteristic hESC markers, displayed a normal karyotype and retained pluripotency throughout 25 passages. In this study, however, only human ESCs were evaluated. Just a few months later, a new polymeric sub- 
strate, poly(methyl vinylether-altmaleic anhydride), that can support both hESC and iPSC self-renewal, was identified through a highthroughput screening approach (Brafman et al., 2010). Both cell types exhibited their characteristic morphology and grew as tightly clustered colonies expressing pluripotency markers, such as OCT4, NANOG, and SOX2 over five passages.

A disadvantage of the techniques described earlier is that serum supplemented, chemically undefined cell culture media is used. In these media, fetal bovine serum or similar serum is used to provide growth factors for stem cell adhesion and proliferation. However, the type or concentration of individual growth factors is not fully characterized and often varies between batches. Self-renewal of pluripotent cells on polymeric substrates was advanced by the development of a complete chemically defined cell culture system with serum-free media (Irwin et al., 2011). In this study, the pluripotency of hESCs was maintained on aminopropylmethacrylamide (APMAAm) for over 20 passages in chemically defined mTeSRTM1 media. This synthetic and defined cell culture system does not require the prior attachment of peptides or proteins to promote cell attachment and is free of complex, undefined culture conditions.

The mechanisms explaining why some polymeric substrates can support self-renewal of pluripotent stem cells are still not clear. It is speculated that the hydrolysis products of the polymers (e.g., carboxyl and sulfonyl groups) may mimic functional features of proteins that support self-renewal (Brafman et al., 2010). An alternative hypothesis is that the existence of specific functional groups on the polymer substrate either stimulates the production of endogenous proteins or promotes the adsorption of exogenous proteins that support self-renewal (Brafman et al., 2010). Indeed, bovine serum albumin in the mTESRTM1 media was identified to be critical for cell adhesion and potentially self-renewal of pluripotent stem cells on APMAAm surfaces (Irwin et al., 2011).

\section{D Scaffolds}

Cells can behave differently in 2D and 3D systems. For instance, tumor cells grown in 3D culture are relatively more resistant to cytotoxic drugs compared with their response in conventional 2D culture (Li et al., 2010). There has been increasing agreement that 3D matrices provide better model systems for physiologic situations (Weaver et al., 1997; Zhao et al., 2006a) such as enhanced cell-cell contact or communications. Below, we examine how the properties of 3D fibrous scaffolds, hydrogels, and composites mediate cell adhesion, viability, and proliferation.

Electrospun fibers of various natural polymers, including collagen and fibrin, are used to fabricate 3D scaffolds. Fiber diameter ranges from $\sim 100$ to $600 \mathrm{~nm}$ promote cell adhesion and proliferation. (Kitazono et al., 2004; Bao et al., 2011; Pant et al., 2011; Wei et al., 2011; Wu et al., 2011). Compared to microfibers, cells develop smaller focal adhesion complexes and exhibit higher proliferation on nanofibers (Hsia et al., 2011). Increasing the porosity and surface area of fibrous scaffolds better supports cell migration into the scaffold, increasing the adhesion and proliferation of cells (RnjakKovacina et al., 2011).

The orientation of the fibers can also affect cell adhesion and viability (Hsieh et al., 2010). For example, a physical hydrogel blend of hyaluronan and methylcellulose incorporating electrospun fibers of collagen or poly(3-caprolactoneco-D,L-lactide) was developed to promote cell-synthetic matrix interactions and influence NSC behavior. Although collagen scaffolds facilitate NSC transplantation and help recovery of an injured spinal cord (Hatami et al., 2009), electronspun collagen fibers in HAMC hydrogels inhibit NSC survival and proliferation. The fine, fragmented, and tangled struc- tures of the less oriented collagen fibers are thought to be responsible for these inhibitory effects. Indeed, human neural precursors (NPs) on aligned polycaprolactone fiber scaffolds exhibit a higher viability than on randomly orientated fibers (Mahairaki et al., 2011). Human NPs seeded on aligned fibers acquire a spindle-like shape and extended processes parallel to the fiber axis, whereas NPs on plain tissue culture surfaces or random fiber substrates form nonpolarized neurite networks (Mahairaki et al., 2011). These morphological differences are due to the rearrangement of cytoskeletal constituents, a process that in turn can influence cell phenotype and function via established links with intracellular signaling pathways (Mahairaki et al., 2011).

Hydrogels or polymers with high water content (>99\% water), are another important class of 3D scaffolds. Hydrogels can be crosslinked via chemical bonds, ionic interactions, hydrogen bonds, hydrophobic interactions, or physical bonds, and have been extensively studied platforms because of their 3D nature, biocompatibility, and versatility in processing (Tian et al., 2005; Thonhoff et al., 2008; Banerjee et al., 2009; Ren et al., 2009; Hsieh et al., 2010; Shanbhag et al., 2010). Hydrogels can be synthesized by various methods, such as radical polymerization, $\mathrm{Mi}$ chael addition chemistry, click chemistry, and a variety of functional moieties can be incorporated to enhance biodegradability and biocompatibility. Growth factors, cytokines, and other chemical additives can also be incorporated into hydrogels to mediate cell activity (Liu et al., 2010b).

Adhesion and proliferation of stem cells can be influenced by hydrogel properties, such as hydrogel concentration and stiffness. For example, human MSCs shrink and degenerate on concentrated PF127 and PuraMatrix hydrogels, and the viability of human NSCs decreases as the concentration of PF127 and Puramatrix increases (Thonhoff et al., 
2008). The mechanism controlling adhesion is unclear, but it is possibly due to a complex dynamic between cytotoxicity and growth factor stimulation or the release of harmful or acidic byproducts during degradation of the hydrogel (Thonhoff et al., 2008). Compared to $2 D$ surfaces, the stiffness of 3D hydrogels affects cell proliferation in a more complex way. Increasing the hydrogel stiffness decreases the proliferation of NSCs when encapsulated in 3D alginate hydrogels (Banerjee et al., 2009), whereas hydrogels enhance cell self-organization and subsequent tissue development (Miyajima et al., 2011). In contrast, smooth muscle cell proliferation in 3D PEG-conjugated fibrinogen hydrogels does not depend on gel stiffness (Peyton et al., 2008).

Composite scaffolds offer biological, chemical, and mechanical advantages that go beyond what each individual component can provide. For example, the natural polymer, fibronectin, is known for its ability to promote cell adhesion. Another natural polymer, chitosan (CS), can promote differentiation of stem cells to several lineages. The combination of these two polymers can offer a more versatile scaffold for tissue regeneration (Chen et al., 2011; Chung et al., 2011; Pei et al., 2011). However, one problem that exists in combining natural polymers is that crosslinking molecules, which are used to stabilize the construct, often lead to in vivo complications, including graft failure (Heydarkhan-Hagvall et al., 2008). Another type of composite is the combination of two synthetic polymers, for example, PLGA and polyacrylic acid (PAA), where PLGA is biocompatible and degradable, while PAA provides better adhesive ability (Endres et al., 2003; Cao et al., 2011). The hybridization of synthetic and natural polymers can also offer improved biological and mechanical properties (Jiao et al., 2007; Craciunescu et al., 2008; Heydarkhan-Hagvall et al., 2008; Venugopal et al., 2008; Liu et al., 2009; Liao et al., 2010).
Incorporating polymeric and inorganic materials is another way to create composite materials with superior mechanical and biological properties. Inorganic components, such as hydroxyapatite, can improve protein adsorption and subsequent cell adhesion (Leonova et al., 2006; Zhao et al., 2006a; Dimitrievska et al., 2008; Li et al., 2009; Venugopal et al., 2010; Akkouch et al., 2011). Mineralized polymer surfaces can also be used to provide sustained release of growth factors and genes (Murphy et al., 2000; Luong et al., 2006; Luong et al., 2009; Segvich and Kohn, 2009). Apatites and bioactive glasses can also neutralize the acidic byproducts of polymer degradation, helping to maintain $\mathrm{pH}$ within physiological ranges, supporting cell function, and minimizing long-term adverse host responses (Roether et al., 2002; Yang et al., 2006; Zhao et al., 2006a).

\section{Surface Functionalization}

As the first step in the sequence of cell-biomaterial interactions, initial adhesion of anchoragedependent cells is crucial to the subsequent cell proliferation and differentiation. Many methods are used to physically modify biomaterial surfaces to increase cell adhesion, including creating surface roughness, topography, and patterning (Vandrovcova and Bacakova, 2011). In general, nanostructured substrates with irregularities smaller than $100 \mathrm{~nm}$ are more favorable to cell adhesion and growth than microstructured substrates (Bacakova et al., 2011). Trends in cell adhesion and proliferation with increased roughness are inconsistent though (Zhang et al., 2010b). Some literature shows that optimal cell adhesion is obtained with small roughness ratios (Ranella et al., 2010), while other literature shows opposite results (Lohmann et al., 2000; Marinucci et al., 2006; Zhao et al., 2006b; Ponader et al., 2008). One of the explanations for these contradictory results is that various methods (e.g., acid-etching vs. sandblasting) used to create different surface roughness ratios on substrates changes surface reactivity or introduced new surface chemistry (Zhang et al., 2010b).

For polymeric materials, immobilization of proteins, such as fibronectin, laminin, and collagen, or peptides, such as RGD and YIGSR, on biomaterial surfaces are the main chemical methods to promote cell adhesion and proliferation (Cheng and Teoh, 2004; Jeong et al., 2005; Shin et al., 2008; Segvich et al., 2009a; Segvich et al., 2009b). These molecules can increase hydrophilicity and surface charge, conditions that facilitate integrin-adhesion molecule interactions and are favorable to cell adhesion. (Shin et al., 2008; Pan et al., 2009; Lundin et al., 2011). However, the stability of these immobilized molecules is dependent on the biomaterial surface. As an example, the anionic ions, tosylate (TsO), perchlorate $\left(\mathrm{ClO}_{4}\right)$, and chloride $(\mathrm{Cl})$, doped on polypyrrole (PPy) degrade over time under physiological conditions, resulting in low NSC viability (Lundin et al., 2011).

Surface modification with layerby-layer assembly can enhance cell adhesion (Boura et al., 2003; D'Britto et al., 2009). The nature of the substrate is largely determined by the characteristics of the outmost layer. For example, bioactive multilayer films composed of PAA- $b$-PLGA and CS assembled on the surface of PLLA films support better attachment and proliferation of human adipose-derived stem cells than PLLA films, because of the more hydrophilic PAA block chains (Cao et al., 2011). Similarly, the interactions of the RGD domain of FN and the receptors on MSCs are responsible for the higher cell mass on CNT/ CS/FN surfaces than on CNT/CS and CNT/CS/HA surfaces (Chung et al., 2011).

\section{CONTROL OF CELL DIFFERENTIATION ON POLYMERS}

Key components in the cellular microenvironment that influence 
TABLE 2. Properties of Polymeric Materials Controlling Stem Cell Differentiation

\begin{tabular}{|c|c|}
\hline Physical properties & $\begin{array}{l}\text { Roughness, stiffness, topography, pore size, porosity, pore connectivity, } \\
\text { fiber diameter, fiber orientation, and surface charge }\end{array}$ \\
\hline Chemical properties & $\begin{array}{l}\text { Composites, polymer concentration, density of crosslinker, hydrophobicity, } \\
\text { surface functionalization with peptides, functional groups, } \\
\text { adhesion molecules, and growth factors }\end{array}$ \\
\hline
\end{tabular}

stem cell differentiation to more committed lineages include soluble factors, cell-cell contact, and cellmatrix interactions (Discher et al., 2009). One of the goals of biomaterial design in stem cell engineering is to control the differentiation of these cells using substrate properties (Table 2). However, the ability to design novel materials has been limited by a poor understanding of the complex signaling events that influence cell differentiation (Fisher et al., 2010). Furthermore, key components involved in directing cell differentiation often interplay and change temporally and spatially. In response to these dynamic and complex changes in the microenvironment, stem cell responses to the extracellular environment are difficult to predict, and therefore, contribute to contradictory results in the literature.

The type and magnitude of physical, chemical, and biological cues can induce stem cell differentiation into neurogenic, osteogenic, chondrogenic, and myogenic lineages, respectively. Therefore, we will discuss how these different types of cues that can be designed into a biomaterial can dictate stem cell differentiation to specific cell lineages.

\section{Neurogenic Differentiation}

Recovery of neuronal networks is limited by the inability of the nervous system to self repair after injury or trauma (Nisbet et al., 2009). Among the polymeric biomaterials, only a subset are suitable for soft tissue engineering, especially nerve regeneration, owing to limitations in mechanical properties such as stiffness ( $\mathrm{Gu}$ et al., 2010). Polymers with similar mechanical properties to the native tissues they are targeted to replace are preferred for tissue engineering (Subramanian et al., 2009). The stiffness of brain tissue is $\sim 500 \mathrm{~Pa}$ (Saha et al., 2008). Therefore, substrates with stiffness in the range of $\sim 100$ to $500 \mathrm{~Pa}$ are ideal for neural tissue regeneration (Engler et al., 2006; Saha et al., 2008; Banerjee et al., 2009). For example, PGA is relatively rigid and not mechanically suitable for transplantation into neural tissue (Thonhoff et al., 2008).

\section{Polymer hydrogels}

An ideal biomaterial for neural transplantation would have the ability to be mixed with stem cells and injected in a fluid form (Thonhoff et al., 2008). It is beneficial if the material is hydrophilic and has a stiffness of $\sim 100$ to 500 Pa (Gu et al., 2010). Meanwhile, the porous network and interconnectivity of the scaffold need to be maintained in hydrated conditions, to facilitate the transportation of nutrients, oxygen, and metabolites and tissue ingrowth. Hydrogels, as a class of polymeric materials, meet all of these requirements (Gu et al., 2010).

Hydrogels are soft, elastic, water-swollen polymeric structures cross-linked either by covalent bonds, physical cross-links (e.g., entanglements), hydrogen bonds, or strong van der Waals interactions. Attention has been given to these materials for neuroengineering because of their flexibility in processing and handling.

One of the most common ways to direct neurogenic differentiation through hydrogels is to incorporate growth factors on peptide sequences into the gel via either simple mixing or covalent bonding to the gel network. For example,
IKVAV, a peptide-derived from laminin, and brain-derived neurotrophic factor (BDNF), reduce neuronal death, induce neuronal differentiation of hMSCs (Park et al., 2010), and promote neuronal regeneration in several models (Tobias et al., 2001; Tuszynski et al., 2003; Katz and Meiri, 2006). Growth factors can also be delivered by genetically engineering cells. An example of this strategy is the engineering of fibroblasts to act as a controlled delivery system to continuously express the neurotrophic factors BDNF and NT-3 (Shanbhag et al., 2010). By utilizing this strategy, alginate constructs can serve as a microenvironment for neural progenitor cell (NPC) differentiation, representing a promising bioengineered solution for neural repair.

In the studies summarized above, proneurogenic growth factors were immobilized on material surfaces. Polymeric biomaterials can also be used to release factors for the purpose of blocking inhibitors of tissue regeneration. For example, Nogo-66 and $\mathrm{NgR}$ are important receptors inhibiting neuronal regeneration. Antibodies (e.g., IgG) covalently attached to biodegradable HA hydrogels have been used to block the function of Nogo-66 and NgR to treat brain injury in rodents (Tian et al., 2005). Although a sustained release of IgG was observed, cell culture experiments showed that NSC differentiation on the same HA substrates coated with the same antibody was similar to that on bare HA surfaces (Pan et al., 2009). These results indicate that cell-material interactions in vitro may not be predictive of cell-material interactions in vivo and that neuronal tissue regeneration requires further investigation. 
Besides being used as a delivery vehicle for growth factors, several properties of hydrogels can be tuned to control cell differentiation. For example, lower concentrations $(0.8-3 \%)$ of Matrigel support migration of human NPCs and neuronal differentiation. However, when the concentration of Matrigel increases to $50 \%$, neurogenic differentiation is inhibited (Katakowski et al., 2005; Flanagan et al., 2006; Thonhoff et al., 2008).

Another property of hydrogels that affects lineage commitment and cell differentiation is stiffness. 2D polymer substrates with moduli ranging from 10 to $10,000 \mathrm{~Pa}$ affect differentiation of adult NSCs (Saha et al., 2008), with substrates having moduli similar to brain tissue (100-500 Pa), maximizing NSC differentiation. Similarly, when NSCs are encapsulated within 3D alginate hydrogels, the greatest expression of the neuronal marker $\beta$-tubulin III is observed on the softest hydrogel (Banerjee et al., 2009), indicating a modulus value near that of brain tissues best promotes neuronal differentiation. The mechanisms by which the mechanical properties of hydrogels influence stem cell commitment are not clear yet, but it appears that cytoskeletal motors may be involved in matrix-elasticity sensing, which is responsible for neuronal differentiation (Banerjee et al., 2009; Discher et al., 2009). Promotion of neural differentiation on 2D and 3D biomaterials of lower stiffness was confirmed by other studies using other polymer substrates such as polyacrylamide gels, and alginate hydrogels (Engler et al., 2006; Saha et al., 2008; Wang et al., 2010b).

\section{Nonhydrogel polymer substrates}

Nanoscale fibers favor neural differentiation of both NSCs and human ES cell-derived NPs compared to microscale fibers (Yang et al., 2005; Mahairaki et al., 2011). The orientation and diameter of polymer fibers also affect neuronal differentiation. For example, the degree of differentiation of NPs is higher on aligned nanopolycaprolactone and micro- polycaprolactone fibers than on random fibers and on 2D tissue culture plate substrates (Mahairaki et al., 2011). Differentiation of NSCs on PLLA polymers, however, is independent of fiber alignment (Yang, 2005), suggesting that material chemistry is a covariate with stiffness in controlling differentiation. The signaling pathways responsible for the effects of matrix architecture on stem cell function have yet to be elucidated, but it is hypothesized that a lineage specification mechanism may involve cytoskeletal and nuclear rearrangements induced by the matrix architecture (Mahairaki et al., 2011).

Although a majority of studies have focused on a direct control of biochemical, physical, and mechanical cues on stem cell differentiation, stem cell microenvironments can also be manipulated using conducting polymer scaffolds (Lundin et al., 2011). The general idea behind using conducting polymers is that bulk properties (e.g., volume, conductivity and mechanical properties) and surface properties (e.g., surface tension and chemistry) dynamically change when the redox states of the polymer are reversibly switched (Causley et al., 2005; Robinson et al., 2006). For example, with the conducting polymer PPy used in neural tissue engineering, the addition of anionic dopants of varying molecular weight and chemical character: dodecylbenzenesulfonate, $\mathrm{TsO}_{2} \mathrm{ClO}_{4}$, and $\mathrm{Cl}$ is hypothesized to control cell differentiation. PPy doped with the laminin peptide sequence RNIAEIIKDI or nerve growth factor enhances neuronal differentiation of hESCs (Lee et al., 2009b; Zhang et al., 2010a). Various composites made of PPy and other polymers such as PLGA also enhance adhesion, proliferation, and neurogenic differentiation of stem cells (Lee et al., 2009a; Liu et al. 2009, 2010a-d, 2011, Wei et al. 2010).

\section{Osteogenic Differentiation Surface functionalization}

Cell-matrix interactions conducive to osteogenic differentiation can be enhanced by surface functionalization of polymers with different peptide sequences, growth, or differentiation factors. Common techniques of surface functionalization include chemical modifications via cross-linking polymer chains with bioactive factors, physical modifications via physisorption of the molecules onto the surface, or physical entrapment (Alvarez-Barreto et al., 2011).

One strategy to functionalize biomaterials surfaces that has received extensive study is the tethering of RGD peptide sequences (Massia and Hubbell, 1991a; Massia and Hubbell, 1991b; Drumheller and Hubbell, 1994; Hubbell, 1995; Hern and Hubbell, 1998; Kao et al., 2001; VandeVondele et al., 2003; Fittkau et al., 2005; Meinhart et al., 2005; Gurav et al., 2007). This peptide motif is found in many bone ECM molecules, including fibronectin, bone sialoprotein, and osteopontin (Lee et al., 2007). The positive role of RGD in cell adhesion has been widely demonstrated with various materials, including glasses, hydroxyapatite, and polymers (De Giglio et al., 2000; Morgan et al., 2008; Alvarez-Barreto et al., 2011). Support of osteogenic differentiation by the presence of RGD is also dose-dependent (Meinel et al., 2004; Shin et al., 2005; AlvarezBarreto et al., 2011). Other peptides and ligands such as the collagen-mimetic peptide, GFOGER, can accelerate and increase bone formation, and improve osseointegration of bone into an implant in vivo (Reyes et al., 2007; Petrie et al., 2008; Phillips et al., 2008; Wojtowicz et al., 2010).

Although the majority of literature focuses on a single surface functionalization parameter (e.g., RGD concentration) on cell differentiation, combining surface functionalization with other parameters, such as dynamic flow, can have a synergistic effect (Alvarez-Barreto et al., 2011). For example, under flow perfusion, which introduces dynamic shear forces on cells, RGD modification of PLLA scaffolds has a more pronounced effect on 
the differentiation of MSCs. The combined effects of flow perfusion and RGD on differentiation are also more prominent on titanium (Holtorf et al., 2005). Another interesting phenomenon is that there is a critical RGD concentration that yields the greatest extent of differentiation, and this optimal concentration is dependent on the flow rate. With increasing flow rate, the optimal concentration of RGD for cell differentiation decreases (Alvarez-Barreto et al., 2011). The dual roles of the integrin receptor $\alpha_{v} \beta_{3}$ either in promoting cell adhesion or inhibiting cell differentiation explains the existence of an optimal RGD concentration for cell differentiation. Higher flow rate can enhance the cell-matrix interaction, and therefore, increase the inhibiting effect of receptor $\alpha_{v} \beta_{3}$. Consequently, the optimal modification level shifts to a lower concentration.

Beside small peptide motifs, large molecules, such as fibrin and hyaluronic acid that favor cell adhesion, can be coated onto biomaterial surfaces. However, these large molecules do not directly signal cells to undergo osteogenic differentiation. Instead, they create a suitable environment for the activity of inductive factors, such as bone morphogenetic protein (BMP)-2 (Kang et al., 2011). For example, the activity of alkaline phosphatase in human ASCs cultured on fibrin and hyaluronic acid modified scaffolds followed by BMP-2 loading was significantly higher than that of ASCs on scaffolds without BMP-2 or just BMP-2 supplemented cell culture medium.

\section{Composites}

Many types of polymeric materials have been investigated for bone tissue engineering. Among these materials, most attention has focused on poly ( $\alpha$-hydroxy) esters, such as PLA, PGA, and PLGA (Cordonnier et al., 2011). However, their biodegradability, soluble factor release kinetics, mechanical properties, and process ability differ depending on stereochemistry and copolymer ratio
(Costa-Pinto et al., 2009; Aydin et al., 2011). By combining polymers with different properties, a scaffold with a more desirable combination of properties can be obtained. One example would be the matching of polymeric scaffold degradation rate with that of in situ host site healing by adjusting the relative amount of PGA and PLGA (Hutmacher, 2000). The matching of rates minimizes adverse reactions (e.g., inflammatory) and is critical for the clinical success of tissue engineered substitutes. Other examples of composites used in bone tissue engineering are the mixture of naturally derived materials, including collagen, CS, and hyaluronic acid containing specific ligands for directing cell differentiation, with synthetic polymers whose physical properties are superior and more easily controllable (Chen et al., 2011).

It remains a challenge to separate the various biomaterial parameters that control stem cell differentiation. To partially solve this problem, hydrogels of PEG monomethacrylate, poly(propylene glycol) monomethacrylate, and methacrylic alginate (MA) have been developed (Cha et al., 2011). In this system, scaffold variables of charge density and hydrophobicity are separately controlled by controlling the mass fractions of MA and PPGmM, and porosity is controlled via lyophilization, providing a versatile platform enabling the independent control of the matrix variables. An investigation of poly( $\mathrm{N}$-isopropylacrylamideco-acrylic acid) hydrogel with independently tuned matrix stiffness and peptide concentration revealed that these matrices induced bone regeneration only when protease degradable crosslinks were used to create the network (Chung et al., 2006). Similar systems with independently tunable properties are also used for systematic optimization of material properties that lead to enhanced cell adhesion, proliferation, and tissue regeneration (Healy, 2004; Wall et al., 2010).

Bone is composed of an organic and inorganic mineral matrix. Therefore, it is also relevant to make a composite material consisting of both organic polymer and inorganic bioactive ceramics, such as tricalcium phosphate, hydroxyapatite, and bioactive glasses. In fact, many in vitro and in vivo studies have already demonstrated that polymeric materials containing ceramic second phases or coated with ceramics exhibit at least three improvements over polymers: enhanced bioactivity, better mechanical properties, and structural integrity, and less adverse host reactions after implantation (Roether et al., 2002). Ceramic materials such as bioactive glasses can form a direct bond to living bone tissue, while most polymeric materials are usually encapsulated by fibrous tissue in vivo. Therefore, the incorporation of a polymer with ceramic materials can improve the bioactivity of the scaffold. Adhesion proteins also more easily adsorb to ceramic surfaces (Zhao et al., 2006a), resulting in increased cell adhesion. Ceramic surfaces also induce the formation of carbonated apatite when placed in physiological media. This calcium phosphate layer plays an important role in mediating cellular responses, including cell differentiation (Murphy et al., 2005). Another advantage of ceramics is that the dissolution products of bioactive glasses and calcium silicate promote the expression of osteogenic genes at a critical concentration of $\mathrm{Ca}^{2+}$ and/or Si (Xynos et al., 2000a, b; Zhang et al., 2010b).

To make 3D polymer/ceramic composites, ceramic particles are infiltrated into porous polymeric matrices by solid-liquid phase separation or electrophoretic deposition, or one component is coated on the other using techniques such as slurry-dipping technique or mineral precipitation (Roether et al., 2002; Zhao et al., 2006a). The former way of synthesizing composites is inspired by the hierarchical structure of bone, where calcium phosphate particles of a nano size are embedded into an organic matrix. However, organic/inorganic composites fabricated in this way often fail to distribute the ceramic particles 
uniformly through the polymer matrix. Therefore, the original interconnected porous structure can become blocked, and cell proliferation and differentiation are negatively affected. In contrast, making a composite material by coating techniques can create a more uniform and reproducible ceramic layer along the walls of pores, especially if flow is used (Roether et al., 2002; Segvich et al., 2008, 2009b), making the output of cell differentiation more controllable and predictable.

\section{Chondrogenic Differentiation}

To develop a stable and efficient strategy for directing differentiation of stem cells into a chondrogenic lineage, various material design approaches have been investigated (Heymer et al., 2009; Liu et al., 2010d; Anderson et al., 2011; Lim et al., 2011; Park et al., 2011b), including manipulating polymeric properties, such as macromer density, incoporating growth and differentiation factors into the polymeric substrate or coating, immobilizing signaling factors on the polymer surface, and making polymer composites.

\section{Substrate Properties}

Some polymer substrates intrinsically support and enhance chondrogenic differentiation of stem cells. One example is collagen type II; compared to alginate and collagen type I, collagen type II promotes expression of the chondrogenic genes sox9, collagen type II, aggrecan, and COMP (Bosnakovski et al., 2006). The shape of cells on type II collagen is also more rounded compared to type I collagen. Blocking the cell surface receptor $\beta 1$ integrin reduces chondrogenic gene expression and also eliminates differences in Rock 1 and Rock 2 gene expression and cell shape. Therefore, collagen type II provides inductive signaling for chondrogenic differentiation by evoking a round cell shape through the $\beta_{1}$ integrin-mediated Rho A/Rock signaling pathway (Lu et al., 2010).
Dynamic loading can affect the movement and distribution of large molecules in dense hydrogels. Therefore, it is relevant to investigate the effect of variations in macromer density on chondrogenesis. For example, chondrogenesis and matrix formation are proportional to macromer density in methacrylated hyaluronic acid hydrogels, due to a greater probability of receptor-mediated interaction with the high density macromer material. However, a higher macromer density yields functionally inferior constructs (Erickson et al., 2009) due to lower permeability of these construct, where only limited matrix expansion by cells occurs.

The majority of studies have focused on the effect of mechanical cues on cell differentiation statically. However, an anionic hydrogel system, PEG-chondroitin sulfate (PEG/CS), undergoes reversible, anisotropic bending in an electric field (Lim et al., 2011). By using this unique property, dynamic mechanical and electrical cues can be simultaneously provided to cells. The magnitude of mechanical cues can be tuned through hydrogel crosslink density. More interestingly, the mechanical and electrical cues can be independently varied, which allows the investigation of one factor while maintaining the other one unchanged.

\section{Growth factors}

Chondrogenic differentiation of stem cells can be induced by growth factors and signaling molecules, including transforming growth factor- $\beta$ (TGF $\beta$ )-1, insulinlike growth factor1 (IGF1), BMP2, BMP7, growth and differentiation factor5 (GDF5), glucosamine (GLCN), dexamethasone, vitamin $C$, and retinoic acid (Hwang et al., 2006; Toh et al., 2010). The induction effect of these factors is dose, temporally, and spatially dependent (Hwang et al., 2006; Erisken et al., 2011). For example, a 2-mM GlcN supplement in standard chondrogenic differentiation medium increases levels of aggre- can mRNA, and tissue-specific ECM accumulation from ESC compared to 0 - and 10-mM concentrations (Hwang et al., 2006). As an example of the spatial effect of growth factors, when human MSCs are seeded on graded poly(e-caprolactone) with concentration gradients of two bioactive agents, insulin and $\beta$-glycerophosphate ( $\beta$-GP), chondrogenic differentiation is increased at insulin-rich locations and osteogenic differentiation is increased at $\beta$-GP-rich locations (Erisken et al., 2011).

TGF- $\beta 1$ also promotes chondrogenic differentiation. For example, TGF- $\beta 1$ can be encapsulated with ASC into carrageenan-based hydrogels to enhance chondrogenic differentiation (RoCha et al., 2011). A coupling of TGF- $\beta 1$ with bone marrow MSC macroaggregates in a PLGA scaffold also forms cartilaginous tissue (Liu et al., 2010d). Another interesting strategy of using TGF- $\beta 1$ is to incorporate growth factor-loaded PLGA polymer microspheres within hMSC aggregates themselves. This approach promotes homogeneous cell differentiation across the cell aggregates, which is not usually seen in conventional cell aggregate culture, since the induction effect is limited by the diffusion of the chondrogenic growth factor from the culture medium into the aggregate and peripheral cell layers.

The use of a single growth factor may not provide all of the necessary signals required for differentiation (Mohan et al., 2010). A combination of two or more induction factors can promote chondrogenic differentiation of stem cells more efficiently (Sharma et al., 2007; Mohan et al., 2010; Toh et al., 2010). The design of biomaterials systems to deliver combinations of factors is motivated by the in vivo milieu, where the formation of a proper chondrogenic phenotype is regulated by the combined action of multiple growth factors spatially and temporally (Thorp et al., 1992). Results from both in vitro and in vivo experiments show that a combination of TFG $\beta$ 3 and BMP2 (Mohan et al., 2010) 
or TGF $\beta$-3 and hyaluronic acid (Sharma et al., 2007) promotes more chondrogenic tissue formation than any of these factors individually. The choice of factors and sequence of delivery play important roles in controlling chondrogenic differentiation. For example, TGF- $\beta 1$ together with BMP7 yields a more homogenous hyaline-like cartilaginous tissue than a combination of TGF- $\beta 1$ with IGF1, BMP2, and GDF5 (Toh et al., 2010).

\section{Composites}

Similar to directing other stem cell lineages, a combination of different polymeric materials can provide appropriate mechanical strength, biodegradability, biocompatibility, and surface characteristics that promote cell adhesion and chondrogenic differentiation (Moutos et al., 2010; Ragetly et al., 2010). For example, CS, a natural biomaterial, which has adequate mechanical properties for supporting chondrogenesis and cartilage formation, but limited cell adhesion ability, can be coated with type II collagen to increase cell adhesion and chondrogenic differentiation (Ragetly et al., 2010). A thermosensitive hydrogel, CS glycerol-phosphate (CGP) lacks mechanical properties, but the addition of starch to this material improves its storage modulus, and viscoelastic properties. Chondrogenic differentiation of ASCs and cartilage matrix accumulation can be increased on starch incorporated CGP (Sa-Lima et al., 2010).

Another approach to synthesizing composite scaffolds for cartilage regeneration is the fabrication of biphasic or multiphasic scaffolds made of a cartilage layer over a subchondral bone region (Heymer et al., 2009). This concept allows the implementation of variations in mechanical, structural, and chemical properties in each layer to mimic the natural structure of osteochondral tissue (Heymer, 2009). In one example, a multiphasic composite scaffold contains an upper collagen type I fiber layer for articular cartilage repair, separated by a hydrophobic interface from a lower PLA for bone repair. With TGF $\beta$ - 1 , hMSCs secret glycosaminoglycans and express cartilage-specific markers aggrecan and collagen type II. However, the communication mechanisms between the two distinct regions to promote chondrogenesis in the upper layer are not fully understood. Using biphasic strategies, polymers can be integrated with ceramic materials such as hydroxyapatite, to promote the simultaneous growth of bone, cartilage, and a mineralized interface tissue (Taboas et al., 2003; Schek et al., 2004).

\section{Surface functionalization}

As previously discussed, growth factors can be supplemented into cell culture medium or encapsulated into microsphere or bulk materials to induce chondrogenic differentiation of stem cells. Alternatively, growth factors like TGF- $\beta 3$ can be immobilized on the polymer surface. Surface immobilization leads to more controllable spatial distribution, which avoids undesirable side effects in the areas where no growth factor is needed. Besides better spatial control, biomaterial surface engineering can also result in sustained release and reduce the consumption of growth factors in comparison with simple addition of factors to the media (Fan et al., 2011). Among the various ways of immobilizing growth factors, covalent cross-linking can provide longterm growth factor delivery, compared to physical adsorption (Fan et al., 2008; Fan et al., 2011).

Peptide sequences are often tethered on biomaterial surfaces to directly and indirectly affect cell differentiation through receptorintegrin interactions and other mechanisms. Although the peptide RGD is primarily known to facilitate cell adhesion, chondrogenic differentiation of hMSCs has been observed on RGD modified polymer surfaces as well (Liu et al., 2010c; Re'em et al., 2010; Steinmetz and Bryant, 2011; You et al., 2011). However, incorporation of another peptide sequence, KLER, with RGD can lead to more signifi- cant type II collagen and aggrecan gene expression and cartilage ECM production. Because the KLER sequence binds strongly to collagen type II and is responsible for matrix organization instead of directly interacting with cell receptors and activating a specific signaling pathway, these results indicate that an indirect cell-ECM interaction is as important as direct cell-material interactions in controlling chondrogenic diferentiation (Salinas and Anseth, 2010).

Functionalized polymeric surfaces can also be used for gene delivery to induce chondrogenic differentiation. For example, polyethylenimine (PEI) modified PLGA nanoparticles are used to deliver SOX5, SOX6, and SOX9 into human MSCs to enhance chondrogenesis. A surface functionalization step is necessary for the incorporation of DNA on these materials, because neither PLGA nor PEI can bind to DNA. The efficiency of gene transfection following surface functionalization approach is sufficient to switch chondrogenic differentiation of stem cells (Park et al., 2011b).

\section{Myogenic and Endothelial Differentiation}

\section{Growth factors}

Various growth factors can affect the activity of either endothelial cells or their progenitors, including FGF, vascular endothelial growth factor (VEGF), granulocyte colony-stimulating factor, hepatocyte growth factor, and placental growth factor (Beohar et al., 2010). Utilization of these growth factors can elicit proliferative and angiogenic effects (Richardson et al., 2001). However, delivery of these factors from polymeric biomaterials to induce cell differentiation presents a challenge because the cellular responses to these soluble stimuli are dose-dependent, temporally dependent, and spatially dependent. Without appropriate control of release kinetics, these soluble factors may negatively influence cell differentiation (Beohar et al., 2010). 
Therefore, focus has been placed on the design of "smart" materials that can release soluble factors in response to cellular needs or changes in physiological conditions. Growth factors can be released when temperature, $\mathrm{pH}$, or even magnetic field changes (Qiu and Park, 2001; Zhang et al., 2004).

In addition to direct immobilization of growth factors on polymer surfaces, transplanted cells can secrete growth factors that mediate function of stem cells. For example, transplanted cord blood mononuclear cells (CBMNC) seeded on a fibrin matrix were used to treat myocardial infarction in a rat model (Cho et al., 2007). Transplanted human umbilical cord blood cells have the ability to produce various angiogenic growth factors, including VEGF, bFGF, and angiopoietin-1, which can induce angiogenesis in vivo ( $\mathrm{Ma}$ et al., 2005; Yokoyama et al., 2006). Combining CBMNC transplantation and bFGF delivery can enhance neovascularization in the ischemic myocardium. It is also likely that transplanted CBMNCs secrete other angiogenic growth factors, cytokines, and vasoactive factors to enhance angiogenic efficacy, which is also one of the advantages of using biomaterials to transplant cells compared to supplementing individual growth factors (Cho et al., 2007).

\section{$3 D$ composite scaffolds}

Cardiac cells cultured in 3D not only display distinct features that are more representative of native myocardium than cells in 2D culture (Clause et al., 2010), but also show enhanced cell-cell interactions, increased cardiac-specific protein expression, spontaneous beating cell activity, and contractility (Akins et al., 2007; Anderson et al., 2007). However, there are also limitations to 3D culturing. The differentiation state of skeletal muscle-derived stem cells in 3D scaffolds is hard to define, due to the coexistence of many cardiac and skeletal muscle-specific proteins produced by mature and immature cells in the complex 3D structure (Clause et al., 2010).

One important consideration in 3D scaffold design for cardiac tissue engineering is that the scaffold has to accommodate the contractile function of differentiated cardiomyocytes. Cardiomyocytes embedded in a fibrin matrix lose their contractile function and type I collagen also limits the spontaneous contraction of cardiomyocytes (Zimmermann et al., 2002; Gonen-Wadmany et al., 2004; Huang et al., 2007). Materials such as PEGylated fibrinogen hydrogels can retain the contractile phenotype of cardiomyocytes through the combined biological and structural attributes of scaffold, in which physical properties, including biodegradation and compliance, are controlled by the PEG, while the fibrinogen confers biological activity (Shapira-Schweitzer et al., 2009).

Another class of materials that is mechanically compatible with heart muscle and avoids permanent deformation and failure under exposure to long-term cyclic strain is elastomers. However, the acidic degradation products of some elastomers lead to an inflammatory response and therefore can limit cell function. Incorporation of a lightly alkaline second phase, such as 4555 Bioglass ${ }^{\mathbb{R}}$ particles, can buffer the acidic cytotoxicity of degradation products, and also improve the functional activity of cardiomyocytes (Chen et al., 2010).

Despite these positive results, there is still limited information on the use of physical stimuli to control stem cell differentiation into a cardiac lineage. Biomaterial stiffness can guide cardiac differentiation of stem cells. For example, in semi-interpenetrating polymer networks made of collagen, fibronectin and laminin, stiffness can be controlled by controlling the percentage of collagen. Stiffer scaffolds resulting from higher collagen concentrations inhibit endothelial cell differentiation, possibly because increasing the elastic modulus decreases cell apoptosis (Battista et al., 2005). These results are consistent with other studies (Kraehenbuehl et al., 2008), where the stiffness of poly(ethyleneglycol) (PEG)-based extracellular matrices varies with the number of cleavable crosslinker matrix metalloproteinase-sensitive peptides. On soft matrices, embryonal carcinoma (EC) cells express more of the early cardiac transcription factor, $N k \times 2.5$, than its control, embryoid bodies in suspension. In contrast, stiffer matrices decrease the number of Nkx2.5-positive cells.

The range of surface stiffness that induces optimal myogenesis of stem cells is cell-dependent. In the range of 10 to $17 \mathrm{kPa}$, myogenesis of hMSCs occurs maximally (Engler et al., 2006; Lanniel et al., 2011). However, with embryonal carcinoma cells a softer matrix with a modulus of $0.3 \mathrm{kPa}$ enhances cardioprogenitor differentiation more than a stiffer matrix with a modulus of $4 \mathrm{kPa}$ (Kraehenbuehl et al., 2008). With cardiosphere-derived cells, biodegradable poly( $\mathrm{N}$-isopropylacrylamide) hydrogels having a modulus of $30 \mathrm{kPa}$ more significantly upregulate cardiac expression than gels with a modulus of 5 or $\sim 60 \mathrm{kPa}$ (Li et al., 2011).

Besides structure and physical properties, chemical composition of a biomaterial can also be tuned to affect cell myogenic differentiation. When a scaffold is made of collagen, fibronectin, and laminin, the presence of fibronectin stimulates endothelial cell differentiation and vascularization. In contrast, increasing the concentration of laminin enhances cell differentiation into beating cardomyocytes. Because fibronectin and laminin do not induce detectable matrix mechanical and structural modifications, control of differentiation is likely due to the cell adhesion motifs present on these proteins (Battista et al., 2005).

\section{Surface modification}

Peptide ligands can interact with integrin receptors on cell surfaces, mediating cell adhesion and a variety of signaling pathways having 
essential biological consequences for cardiac tissue engineering (Liu et al., 2011). These peptides include RGD, PGLD, and RGDSP (Kraehenbuehl et al., 2008; Yu et al., 2010; Moura and de Queiroz, 2011). Surface modifications of polymeric scaffolds with these peptide sequences can stimulate the differentiation of cardiac progenitor cells, promote cardiac matrix maturation, and induce angiogenesis in vitro. Despite these promising in vitro data, in vivo experiments show no significant difference in angiogenesis between RGD modified alginate microbeads and unmodified ones (Yu et al., 2010). These contradictory results highlight that microenvironmental factors are different between in vitro and in vivo situations, and conclusions drawn from in vitro experiments on substrates functionalized by peptides may not be extrapolated to and be predictive of in vivo function.

Besides peptide sequence, surface functional groups can be introduced into hydrogels through plasma polymerization. These functional groups include amino, carboxylic, and phosphate groups. Surfaces with carboxylic coatings yield higher levels of expression of the myogenic differentiation marker MyoD1 than the other functional groups (Lanniel et al., 2011). The compatibility of carboxylic groups with directing cardiac myocyte function was observed in another study, where an increased number of beating cardiac myocytes was seen on the carboxylic-functionalized surfaces compared to hydroxylfunctionalized surfaces (Natarajan et al., 2008). In spite of the ability to control cardiomyocyte differentiation by manipulating polymer surface chemistry, the mechanisms by which these surface functional groups affect differentiation is not clear.

It is important to note that the stimulating effect of surface functional groups on cardiac differentiation can vary with other material variables, such as stiffness. For example, the addition of collagen to a thermosensitive hydrogel made of polycaprolactone, $\mathrm{N}$-isopropylacrylamide, 2-hydroxyethyl methacrylate, and dimethyl- $\gamma$-butyrolactone acrylate has no effect on the differentiation of cardiosphere-derived cells into a mature cardiac lineage in low modulus hydrogels of $\sim 5 \mathrm{kPa}$, but enhances expression of the cardiac genes MYH6 and CTnT in medium modulus hydrogels of $\sim 30 \mathrm{kPa}$ (Li et al., 2011). However, carboxylic groups on polyacrylamide hydrogels enhance MyoD1 expression by human MSCs on low modulus surfaces of $\sim 10 \mathrm{kPa}$, compared to a lower levels of MyoD1 expression on high modulus surfaces of $\sim 80 \mathrm{kPa}$ (Lanniel et al., 2011).

\section{SUMMARY AND FUTURE DIRECTIONS}

In summary, various factors from the extracellular environment known to control cell adhesion, proliferation, and differentiation have been incorporated into the design of biomaterials to achieve the objective of creating increased communication between biomaterials and their surrounding biological environment. The effects of these material modifications on cell activity are dose-dependent, temporally dependent, and spatially dependent. Biomaterials design and synthesis, as well as other tissue engineering strategies are used to create a controlled microenvironment and mimic the dose-response relations in time and space to favor specific types of cell activity.

Despite the interesting in vitro and in vivo results summarized in this review, the precise control of cell activity by polymeric substrates still represents a major challenge due to complex and dynamic interactions in these multicomponent systems, involving many biological, physical, and chemical processes. For instance, investigations of how polymer stiffness affects cell activity do not account for changes in stiffness in situ over time, as cells lay down ECM to create a "new" substrate. When investigating peptide immo- bilization on polymer surfaces, the distribution of peptide sequences on the surface and how distribution patterns affect cell activity need to be accounted for. Therefore, to gain better understanding of cell-biomaterial interactions, a systematic study that evaluates the role of extracellular factors in a time-dependent manner is required, even if the study is simplified by investigating only one factor. As new methods and strategies become available to fabricate new polymeric substrates with independently controllable properties, and new techniques are able to offer more precise monitoring and characterization of substrate properties and cell activities, better understanding of cellbiomaterial interactions can be achieved in the future. Ultimately, better control of cell-biomaterial interactions will enable advances in tissue engineering to be achieved.

\section{ACKNOWLEDGMENTS}

This work is supported by Tissue Engineering and Regeneration Training Grant, NIH T32DE007057-35 and NIH R01 DE 013380-10. The authors thank useful discussions with Janani Ramaswamy, Harsha Ramaraju, Joseph Gardinier, Erin McNerny, Michael Friedman.

\section{REFERENCES}

Ahearne M, Buckley CT, Kelly DJ. 2011. A growth factor delivery system for chondrogenic induction of infrapatellar fat pad-derived stem cells in fibrin hydrogels. Biotechnol Appl Bioc 58:345-352.

Akins RE, Gratton K, Quezada E, Rutter H, Tsuda T, Soteropoulos P. 2007. Gene expression profile of bioreactor-cultured cardiac cells: activation of morphogenetic pathways for tissue engineering. DNA Cell Biol 26: 425-434.

Akkouch A, Zhang Z, Rouabhia M. 2011. A novel collagen/hydroxyapatite/poly(lactide-co-epsilon-caprolactone) biodegradable and bioactive 3D porous scaffold for bone regeneration. J Biomed Mater Res A 96A: 693-704.

Akpalo E, Bidault L, Boissiere M, Vancaeyzeele C, Fichet O, Larreta-Garde V. 2011. Fibrin-polyethylene oxide interpenetrating polymer networks: new self-supported biomaterials combining the properties of both pro- 
tein gel and synthetic polymer. Acta Biomater 7:2418-2427.

Alvarez-Barreto JF, Landy B, VanGordon S, Place L, DeAngelis PL, Sikavitsas VI. 2011. Enhanced osteoblastic differentiation of mesenchymal stem cells seeded in RGD-functionalized PLLA scaffolds and cultured in a flow perfusion bioreactor. J Tissue Eng Regen Med 5:464-475.

Anderson SB, Lin CC, Kuntzler DV, Anseth KS. 2011. The performance of human mesenchymal stem cells encapsulated in cell-degradable polymer-peptide hydrogels. Biomaterials 32:3564-3574.

Anderson PAW, Muller-Borer BJ, Esch GL, Coleman WB, Grisham JW, Malouf NN. 2007. Calcium signals induce liver stem cells to acquire a cardiac phenotype. Cell Cycle 6:1565-1569.

Anselme $K$, Bigerelle $M$, Noel $B$, Dufresne $E$, Judas $D$, Iost $A$, Hardouin P. 2000. Qualitative and quantitative study of human osteoblast adhesion on materials with various surface roughnesses. J Biomed Mater Res 49:155-166.

Anselme K, Bigerelle M, Noel B, Iost A, Hardouin P. 2002. Effect of grooved titanium substratum on human osteoblastic cell growth. J Biomed Mater Res 60:529-540.

Aydin HM, Korkusuz P, Vargel I, Kilic E, Guzel E, Cavusoglu T, Ucgan D, Piskin E. 2011. A 6-month in vivo study of polymer/mesenchymal stem cell constructs for cranial defects. J Bioact Compat Polym 26:207-221.

Bacakova L, Filova E, Parizek M, Ruml T, Svorcik V. 2011. Modulation of cell adhesion, proliferation and differentiation on materials designed for body implants. Biotechnol Adv 29:739-767.

Banerjee A, Arha M, Choudhary S, Ashton RS, Bhatia SR, Schaffer DV, Kane RS. 2009. The influence of hydrogel modulus on the proliferation and differentiation of encapsulated neural stem cells. Biomaterials 30:4695-4699.

Bao CY, Chen WC, Weir MD, Thein-Han W, Xu HHK. 2011. Effects of electrospun submicron fibers in calcium phosphate cement scaffold on mechanical properties and osteogenic differentiation of umbilical cord stem cells. Acta Biomater 7:4037-4044.

Battista S, Guarnieri D, Borselli C, Zeppetelli S, Borzacchiello A, Mayol L, Gerbasio D, Keene DR, Ambrosio L, Netti PA. 2005. The effect of matrix composition of 3D constructs on embryonic stem cell differentiation. Biomaterials 26:6194-6207.

Beohar N, Rapp J, Pandya S, Losordo DW. 2010. Rebuilding the damaged heart the potential of cytokines and growth factors in the treatment of ischemic heart disease. J Am Coll Cardiol 56:1287-1297.
Bigerelle M, Iost A. 2001. A new method to calculate the fractal dimension of surfaces: application to human cell proliferation. Comput Math Appl 42:241-253.

Bilir A, Erguven M, Zilan A, Oktem G, Korkmaz S, Korkmaz M. 2011. Evaluation and comparison of in vitro biocompatibility of poly (glycolic acid) and poly (lactide-co-glycolide acid) on mature spheroids of tumorigenic and non-tumorigenic cell lines. Turk Klin Tip Bilim 31:1-14.

Bosnakovski D, Mizuno M, Kim G, Takagi S, Okumura M, Fujinaga T. 2006. Chondrogenic differentiation of bovine bone marrow mesenchymal stem cells (MSCs) in different hydrogels: influence of collagen type II extracellular matrix on MSC chondrogenesis. Biotechnol Bioeng 93:11521163.

Boura C, Menu P, Payan E, Picart C, Voegel JC, Muller S, Stoltz JF. 2003. Endothelial cells grown on thin polyelectrolyte mutlilayered films: an evaluation of a new versatile surface modification. Biomaterials 24:35213530.

Brafman DA, Chang CW, Fernandez A, Willert K, Varghese S, Chien S. 2010. Long-term human pluripotent stem cell self-renewal on synthetic polymer surfaces. Biomaterials 31:9135-9144. Cao YF, Li D, Shang CH, Yang ST, Wang JF, Wang XN. 2010. Threedimensional culture of human mesenchymal stem cells in a polyethylene terephthalate matrix. Biomed Mater 5:065013.

Cao B, Yan SF, Zhang KX, Song ZJ, Cao T, Chen XS, Cui L, Yin JB. 2011. A poly(acrylic acid)-block-poly(I-glutamic acid) diblock copolymer with improved cell adhesion for surface modification. Macromol Biosci 11:970-977.

Castellani R, de Ruijter A, Renggli $\mathrm{H}$, Jansen J. 1999. Response of rat bone marrow cells to differently roughened titanium discs. Clin Oral Implants Res 10:369-378.

Causley J, Stitzel S, Brady S, Diamond D, Wallace G. 2005. Electrochemicallyinduced fluid movement using polypyrrole. Synthetic Met 151:60-64.

Cha C, Kim ES, Kim IW, Kong H. 2011. Integrative deign of a poly(ethylene glycol)-poly(propylene glycol)-alginate hydrogel to control three dimensional biomineralization. Biomaterials 32: 2695-2703.

Chan G, Mooney DJ. 2008. New materials for tissue engineering: towards greater control over the biological response. Trends Biotechnol 26:382392.

Chandler EM, Berglund CM, Lee JS, Polacheck WJ, Gleghorn JP, Kirby BJ, Fischbach C. 2011. Stiffness of photocrosslinked RGD-alginate gels regulates adipose progenitor cell behavior. Biotechnol Bioeng 108: 1683-1692.
Chen QZ, Jin LY, Cook WD, Mohn D, Lagerqvist EL, Elliott DA, Haynes JM, Boyd N, Stark WJ, Pouton CW, Stanley EG, Elefanty AG. 2010. Elastomeric nanocomposites as cell delivery vehicles and cardiac support devices. Soft Matter 6:4715-4726.

Chen MW, Le DQS, Baatrup A, Nygaard JV, Hein S, Bjerre L, Kassem M, Zou XN, Bunger C. 2011. Self-assembled composite matrix in a hierarchical 3$D$ scaffold for bone tissue engineering. Acta Biomater 7:2244-2255.

Cheng ZY, Teoh SH. 2004. Surface modification of ultra thin poly (epsilon-caprolactone) films using acrylic acid and collagen. Biomaterials 25:1991-2001.

Cho SW, Kim IK, Bhang SH, Joung BY, Kim YJ, Yoo KJ, Yang YS, Choi CY, Kim BS. 2007. Combined therapy with human cord blood cell transplantation and basic fibroblast growth factor delivery for treatment of myocardial infarction. Eur J Heart Fail 9:974-985.

Chung EH, Gilbert M, Virdi AS, Sena K, Sumner DR, Healy KE. 2006. Biomimetic artificial ECMs stimulate bone regeneration. J Biomed Mater Res A 79A:815-826.

Chung TW, Limpanichpakdee T, Yang MH, Tyan YC. 2011. An electrode of quartz crystal microbalance decorated with CNT/chitosan/fibronectin for investigating early adhesion and deforming morphology of rat mesenchymal stem cells. Carbohydr Polym 85:726-732.

Clause KC, Tinney JP, Liu LJ, Gharaibeh B, Huard J, Kirk JA, Shroff SG, Fujimoto KL, Wagner WR, Ralphe JC, Keller BB, Tobita K. 2010. A Threedimensional gel bioreactor for assessment of cardiomyocyte induction in skeletal muscle-derived stem cells. Tissue Eng C Methods 16:375385.

Cordonnier T, Sohier J, Rosset P, Layrolle P. 2011. Biomimetic materials for bone tissue engineering - state of the art and future trends. Adv Eng Mater 13:B135-B150.

Costa-Pinto AR, Correlo VM, Sol PC, Bhattacharya $M$, Charbord $P$, Delorme B, Reis RL, Neves NM. 2009. Osteogenic differentiation of human bone marrow mesenchymal stem cells seeded on melt based chitosan scaffolds for bone tissue engineering applications. Biomacromolecules 10:2067-2073.

Craciunescu O, Lungu M, Zarnescu O, Gaspar A, Moldovan L. 2008. Polyurethane-based materials covered with natural polymers for medical applications. Mater Plast 45:163-166.

Dawson E, Mapili G, Erickson K, Taqvi S, Roy K. 2008. Biomaterials for stem cell differentiation. Adv Drug Delivery Rev 60:215-228.

D'Britto V, Tiwari S, Purohit V, Wadgaonkar PP, Bhoraskar SV, Bhonde RR, Prasad BLV. 2009. Composites of 
plasma treated poly(etherimide) films with gold nanoparticles and lysine through layer by layer assembly: a "friendly-rough" surface for cell adhesion and proliferation for tissue engineering applications. J Mater Chem 19:544-550.

De Giglio E, Sabbatini L, Colucci S, Zambonin G. 2000. Synthesis, analytical characterization, and osteoblast adhesion properties on RGDgrafted polypyrrole coatings on titanium substrates. J Biomat Sci Polym Ed 11:1073-1083.

Deligianni DD, Katsala ND, Koutsoukos PG, Missirlis YF. 2001. Effect of surface roughness of hydroxyapatite on human bone marrow cell adhesion, proliferation, differentiation and detachment strength. Biomaterials 22:87-96.

Dimitrievska S, Petit A, Ajji A, Bureau MN, Yahia L. 2008. Biocompatibility of novel polymer-apatite nanocomposite fibers. J Biomed Mater Res A 84A:44-53.

Discher DE, Janmey P, Wang YL. 2005. Tissue cells feel and respond to the stiffness of their substrate. Science 310:1139-1143.

Discher DE, Mooney DJ, Zandstra PW. 2009. Growth factors, matrices, and forces combine and control stem cells. Science 324:1673-1677.

Drumheller PD, Hubbell JA. 1994. Polymer networks with grafted cell-adhesion peptides for highly biospecific cell adhesive substrates. Anal Biochem 222:380-388.

Endres M, Hutmacher DW, Salgado AJ, Kaps C, Ringe J, Reis RL, Sittinger $M$, Brandwood A, Schantz JT. 2003. Osteogenic induction of human bone marrow-derived mesenchymal progenitor cells in novel synthetic polymer-hydrogel matrices. Tissue Eng 9:689-702.

Engler AJ, Sen S, Sweeney HL, Discher DE. 2006. Matrix elasticity directs stem cell lineage specification. Cell 126:677-689.

Erickson IE, Huang $A H$, Sengupta $S$, Kestle S, Burdick JA, Mauck RL. 2009. Macromer density influences mesenchymal stem cell chondrogenesis and maturation in photocrosslinked hyaluronic acid hydrogels. Osteoarthritis Cartilage 17:16391648.

Erisken C, Kalyon DM, Wang $\mathrm{HJ}$, Ornek-Ballanco C, Xu JH. 2011. Osteochondral tissue formation through adipose-derived stromal cell differentiation on biomimetic polycaprolactone nanofibrous scaffolds with graded insulin and beta-glycerophosphate concentrations. Tissue Eng A 17:1239-1252.

Fan HB, Tao HR, Wu YN, Hu YY, Yan YN, Luo ZJ. 2011. TGF-beta 3 immobilized PLGA-gelatin/chondroitin sulfate/hyaluronic acid hybrid scaffold for cartilage regeneration. ] Biomed Mater Res A 95A:982-992.
Fan $\mathrm{HB}$, Zhang $\mathrm{CL}$, Li J, Bi L, Qin L, Wu H, Hu YY. 2008. Gelatin microspheres containing TGF-beta 3 enhance the chondrogenesis of mesenchymal stem cells in modified pellet culture. Biomacromolecules 9:927-934.

Fisher OZ, Khademhosseini A, Langer R, Peppas NA. 2010. Bioinspired Materials for Controlling Stem Cell Fate. Accounts Chem Res 43:419-428.

Fittkau $M H$, Zilla $P$, Bezuidenhout $D$, Lutolf M, Human P, Hubbell JA, Davies N. 2005. The selective modulation of endothelial cell mobility on RGD peptide containing surfaces by YIGSR peptides. Biomaterials 26:167-174.

Flanagan LA, Rebaza LM, Derzic S, Schwartz PH, Monuki ES. 2006. Regulation of human neural precursor cells by laminin and integrins. J Neurosci Res 83:845-856.

Freed LE, Engelmayr GC, Borenstein JT, Moutos FT, Guilak F. 2009. Advanced material strategies for tissue engineering scaffolds. Adv Mater 21:3410-3418.

Gonen-Wadmany M, Gepstein L, Seliktar D. 2004. Controlling the cellular organization of tissue-engineered cardiac constructs. Cardiac Engineering: from Genes and Cells to Structure and Function. New York, NY: The New York Academy of Sciences. p 299-311.

Gu HG, Yue ZL, Leong WS, Nugraha B, Tan LP. 2010. Control of in vitro neural differentiation of mesenchymal stem cells in 3D macroporous, cellulosic hydrogels. Regen Med 5:245253.

Gurav N, Lutolf MP, Raeber GP, Hubbell JA, Di Silvio L. 2007. Differentiation of human bone marrow stem cells within RGD functionalised, proteolytically sensitive PEG gels. Tissue Eng 13:1675-1675

Hatakeyama $H$, Kikuchi $A$, Yamato $M$, Okano T. 2005. Influence of insulin immobilization to thermoresponsive culture surfaces on cell proliferation and thermally induced cell detachment. Biomaterials 26:5167-5176.

Hatami M, Mehrjardi NZ, Kiani S, Hemmesi K, Azizi H, Shahverdi A, Baharvand H. 2009. Human embryonic stem cell-derived neural precursor transplants in collagen scaffolds promote recovery in injured rat spinal cord. Cytotherapy 11:618-630.

Hatano $\mathrm{K}$, Inoue $\mathrm{H}$, Kojo $\mathrm{T}$, Matsunaga T, Tsujisawa T, Uchiyama C, Uchida Y. 1999. Effect of surface roughness on proliferation and alkaline phosphatase expression of rat calvarial cells cultured on polystyrene. Bone 25:439-445.

Healy KE. 2004.Control of cell function with tunable hydrogel networks. Conference proceedings: Annual International Conference of the IEEE Engineering in Medicine and Biology Society IEEE Engineering in Medicine and Biology Society Conference, San Francisco, CA 7: 5035.
Hern DL, Hubbell JA. 1998. Incorporation of adhesion peptides into nonadhesive hydrogels useful for tissue resurfacing. J Biomed Mater Res $39: 266-276$

Heydarkhan-Hagvall S, Schenke-Layland $K$, Dhanasopon AP, Rofail $F$, Smith H, Wu BM, Shemin R, Beygui RE, MacLellan WR. 2008. Threedimensional electrospun ECM-based hybrid scaffolds for cardiovascular tissue engineering. Biomaterials 29:2907-2914.

Heymer A, Bradica G, Eulert J, Noth U. 2009. Multiphasic collagen fibre-PLA composites seeded with human mesenchymal stem cells for osteochondral defect repair: an in vitro study. J Tissue Eng Regen Med 3:389-397.

Holtorf HL, Jansen JA, Mikos AG. 2005. Ectopic bone formation in rat marrow stromal cell/titanium fiber mesh scaffold constructs: effect of initial cell phenotype. Biomaterials 26:62086216.

Hsia HC, Nair MR, Mintz RC, Corbett SA. 2011. The fiber diameter of synthetic bioresorbable extracellular matrix influences human fibroblast morphology and fibronectin matrix assembly. Plast Reconstr Surg 127: 2312-2320.

Hsieh A, Zahir T, Lapitsky Y, Amsden B, Wan WK, Shoichet MS. 2010. Hydrogel/electrospun fiber composites influence neural stem/progenitor cell fate. Soft Matter 6:22272237.

Huang YC, Khait L, Birla RK. 2007. Contractile three-dimensional bioengineered heart muscle for myocardial regeneration. J Biomed Mater Res A 80A:719-731.

Hubbell JA. 1995. Biomaterials in tissue engineering. Bio-Technology 13:565-576.

Hutmacher DW. 2000. Scaffolds in tissue engineering bone and cartilage. Biomaterials 21:2529-2543.

Hwang NS, Varghese S, Theprungsirikul P, Canver A, Elisseeff J. 2006. Enhanced chondrogenic differentiation of murine embryonic stem cells in hydrogels with glucosamine. Biomaterials 27:6015-6023.

Idota N, Tsukahara T, Sato K, Okano T, Kitamori T. 2009. The use of electron beam lithographic graft-polymerization on thermoresponsive polymers for regulating the directionality of cell attachment and detachment. Biomaterials 30:2095-2101.

Irwin EE, Gupta R, Dashti DC, Healy KE. 2011. Engineered polymermedia interfaces for the long-term self-renewal of human embryonic stem cells. Biomaterials 32:69126919.

Jeong SI, Kwon JH, Lim JI, Cho SW, Jung $\mathrm{YM}$, Sung WJ, Kim SH, Kim YH, Lee YM, Kim BS, Choi CY, Kim SJ. 2005. Mechano-active tissue engineering of vascular smooth muscle using pulsatile perfusion bioreactors 
and elastic PLCL scaffolds. Biomaterials 26:1405-1411.

Jiao YP, Liu ZH, Zhou CR. 2007. Fabrication and characterization of PLLAchitosan hybrid scaffolds with improved cell compatibility. J Biomed Mater Res A 80A:820-825.

Kang YQ, Scully A, Young DA, Kim S, Tsao H, Sen M, Yang YZ. 2011. Enhanced mechanical performance and biological evaluation of a PLGA coated beta-TCP composite scaffold for load-bearing applications. Eur Polym J 47:1569-1577.

Kao WJ, Lee D, Schense JC, Hubbell TA. 2001. Fibronectin modulates macrophage adhesion and FBGC formation: The pole of RGD, PHSRN, and PRRARV domains. J Biomed Mater Res 55:79-88.

Katakowski M, Zhang ZG, deCarvalho AC, Chopp M. 2005. EphB2 induces proliferation and promotes a neuronal fate in adult subventricular neural precursor cells. Neurosci Lett 385: 204-209.

Katz A, Meiri N. 2006. Brain-derived neurotrophic factor is critically involved in thermal-experiencedependent developmental plasticity. J Neurosci 26:3899-3907.

Kitazono E, Kaneko H, Miyoshi T, Miyamoto K. 2004. Tissue engineering using nanofiber. J Synth Org Chem Jpn 62:514-519.

Korovessis PG, Deligianni DD, Lenke LG. 2002. Role of surface roughness of titanium versus hydroxyapatite on human bone marrow cells response. J Spinal Disord Tech 15:175-183.

Kraehenbuehl TP, Zammaretti $P$, Van der Vlies AJ, Schoenmakers RG, Lutolf MP, Jaconi ME, Hubbell JA. 2008. Three-dimensional extracellular matrix-directed cardioprogenitor differentiation: systematic modulation of a synthetic cell-responsive PEG-hydrogel. Biomaterials 29: 2757-2766.

Kumashiro $\mathrm{Y}$, Yamato M, Okano $\mathrm{T}$. 2010. Cell attachment-detachment control on temperature-responsive thin surfaces for novel tissue engineering. Ann Biomed Eng 38:19771988.

Lanniel M, Huq E, Allen S, Buttery L, Williams PM, Alexander MR. 2011. Substrate induced differentiation of human mesenchymal stem cells on hydrogels with modified surface chemistry and controlled modulus. Soft Matter 7:6501-6514.

Le DM, Kulangara K, Adler AF, Leong KW, Ashby VS. 2011. Dynamic topographical control of mesenchymal stem cells by culture on responsive poly(epsilon-caprolactone) surfaces. Adv Mater 23:3278-3283.

Lee $M H$, Adams CS, Boettiger $D$, DeGrado WF, Shapiro IM, Composto RJ, Ducheyne P. 2007. Adhesion of MC3T3-E1 cells to RGD peptides of different flanking residues: detachment strength and correlation with long-term cellular function. J Biomed Mater Res A 81A:150-160.

Lee JY, Bashur CA, Goldstein AS, Schmidt CE. 2009a. Polypyrrolecoated electrospun PLGA nanofibers for neural tissue applications. Biomaterials 30:4325-4335.

Lee JY, Lee JW, Schmidt CE. 2009b. Neuroactive conducting scaffolds: nerve growth factor conjugation on active ester-functionalized polypyrrole. J R Soc Interface 6:801810.

Leonova EV, Pennington KE, Krebsbach $\mathrm{PH}$, Kohn DH. 2006. Substrate mineralization stimulates focal adhesion contact redistribution and cell motility of bone marrow stromal cells. J Biomed Mater Res A 79A:263-270.

Leor J, Aboulafia-Etzion S, Dar A, Shapiro L, Barbash IM, Battler A, Granot Y, Cohen S. 2000. Bioengineered cardiac grafts - a new approach to repair the infarcted myocardium? Circulation 102:56-61.

Levenberg S, Huang NF, Lavik E, Rogers $A B$, Itskovitz-Eldor J, Langer R. 2003. Differentiation of human embryonic stem cells on three-dimensional polymer scaffolds. Proc Natl Acad Sci USA 100:12741-12746.

Li HY, Chen YF, Xie YS. 2004. Nanocomposites of cross-linking polyanhydrides and hydroxyapatite needles: mechanical and degradable properties. Mater Lett 58:28192823.

Li QW, Chow AB, Mattingly RR. 2010. Three-dimensional overlay culture models of human breast cancer reveal a critical sensitivity to mitogen-activated protein kinase kinase inhibitors. J Pharmacol Exp Ther 332:821-828.

Li JJ, Dou $Y$, Yang J, Yin $Y$ J, Zhang $\mathrm{H}_{\text {, }}$ Yao FL, Wang HB, Yao KD. 2009. Surface characterization and biocompatibility of micro- and nano-hydroxyapatite/chitosan-gelatin network films. Mater Sci Eng C Biomimetic Supramol Syst 29:1207-1215.

Li ZQ, Guo XL, Matsushita S, Guan JJ. 2011. Differentiation of cardiosphere-derived cells into a mature cardiac lineage using biodegradable poly( $\mathrm{N}$-isopropylacrylamide) hydrogels. Biomaterials 32:3220-3232.

Liao GY, Chen LA, Zeng XY, Zhou XP, Xie XL, Peng EJ, Ye ZQ, Mai YW. 2011. Electrospun poly(I-lactide)/poly(epsilon-caprolactone) blend fibers and their cellular response to adipose-derived stem cells. J App Polym Sci 120:2154-2165.

Liao JH, Guo XA, Nelson D, Kasper FK, Mikos AG. 2010. Modulation of osteogenic properties of biodegradable polymer/extracellular matrix scaffolds generated with a flow perfusion bioreactor. Acta Biomater 6:23862393.

Lim HL, Chuang JC, Tuan T, Aung A, Arya G, Varghese S. 2011. Dynamic electromechanical hydrogel matrices for stem cell culture. Adv Funct Mater 21:55-63.

Linez-Bataillon P, Monchau F, Bigerelle M, Hildebrand HF. 2002. In vitro MC3T3 osteoblast adhesion with respect to surface roughness of Ti6A14V substrates. Biomol Eng 19:133-141.

Liu XA, Chen J, Gilmore KJ, Higgins MJ, Liu Y, Wallace GG. 2010a. Guidance of neurite outgrowth on aligned electrospun polypyrrole/poly(styrenebeta-isobutylene-beta-styrene) fiber platforms. J Biomed Mater Res A 94A:1004-1011.

Liu SQ, Tay R, Khan M, Ee PLR, Hedrick JL, Yang YY. 2010b. Synthetic hydrogels for controlled stem cell differentiation. Soft Matter 6:67-81.

Liu SQ, Tian QA, Wang L, Hedrick JL, Hui JHP, Yang YY, Ee PLR. 2010c. Injectable biodegradable poly(ethylene glycol)/RGD peptide hybrid hydrogels for in vitro chondrogenesis of human mesenchymal stem cells. Macromol Rapid Commun 31:11481154.

Liu Y, Vrana NE, Cahill PA, McGuinness GB. 2009. Physically crosslinked composite hydrogels of PVA with natural macromolecules: structure, mechanical properties, and endothelial cell compatibility. J Biomed Mater Res B 90B:492-502.

Liu Y, Wang XT, Kaufman DS, Shen W. 2011. A synthetic substrate to support early mesodermal differentiation of human embryonic stem cells. Biomaterials 32:8058-8066.

Liu LQ, Wu W, Tuo XY, Geng WX, Zhao J, Wei J, Yan XR, Yang W, Li LW, Chen FL. 2010d. Novel strategy to engineer trachea cartilage graft with marrow mesenchymal stem cell macroaggregate and hydrolyzable scaffold. Artif Organs 34:426-433.

Lohmann $\mathrm{CH}$, Bonewald LF, Sisk MA, Sylvia VL, Cochran DL, Dean DD, Boyan BD, Schwartz Z. 2000. Maturation state determines the response of osteogenic cells to surface roughness and 1,25-dihydroxyvitamin D-3. J Bone Miner Res 15:1169-1180.

Lu Z, Doulabi BZ, Huang C, Bank RA, Helder MN. 2010. Collagen type II enhances chondrogenesis in adipose tissue-derived stem cells by affecting cell shape. Tissue Eng A 16:81-90.

Lundin V, Herland A, Berggren $M$, Jager EWH, Teixeira AI. 2011. Control of neural stem cell survival by electroactive polymer substrates. PLoS One 6:e18624.

Luong LN, Hong SI, Patel RJ, Outslay ME, Kohn DH. 2006. Spatial control of protein within biomimetically nucleated mineral. Biomaterials 27:1175-1186.

Luong LN, McFalls KM, Kohn DH. 2009. Gene delivery via DNA incorporation within a biomimetic apatite coating. Biomaterials 30:6996-7004.

Ma N, Stamm C, Kaminski A, Li WZ, Kleine HD, Muller-Hilke B, Zhang L, 
Ladilov Y, Egger D, Steinhoff G. 2005. Human cord blood cells induce angiogenesis following myocardial infarction in NOD/scid-mice. Cardiovasc Res 66:45-54.

Mahairaki V, Lim SH, Christopherson GT, Xu LY, Nasonkin I, Yu C, Mao HQ, Koliatsos VE. 2011. Nanofiber matrices promote the neuronal differentiation of human embryonic stem cell-derived neural precursors in vitro. Tissue Eng A 17:855-863.

Marinucci L, Balloni S, Becchetti E, Belcastro S, Guerra M, Calvitti M, Lilli C, Calvi EM, Locci P. 2006. Effect of titanium surface roughness on human osteoblast proliferation and gene expression in vitro. Int Journal of Oral Maxillofac Implants 21:719-725.

Marklein RA, Burdick JA. 2010. Controlling stem cell fate with material design. Adv Mater 22:175-189.

Massia SP, Hubbell JA. 1991a. Human endothelial-cell interactions with surface-coupled adhesion peptides on a nonadhesive glass substrate and 2 polymeric biomaterials. J Biomed Mater Res 25:223-242.

Massia SP, Hubbell JA. 1991b. An Rgd spacing of $440 \mathrm{~nm}$ is sufficient for integrin alpha-V-beta-3-mediated fibroblast spreading and $140 \mathrm{~nm}$ for focal contact and stress fiber formation. J Cell Biol 114:1089-1100.

Meinhart JG, Schense JC, Schima $H$, Gorlitzer M, Hubbell JA, Deutsch M, Zilla P. 2005. Enhanced endothelial cell retention on shear-stressed synthetic vascular grafts precoated with RGD-cross-linked fibrin. Tissue Eng 11:887-895.

Miyajima $H$, Matsumoto T, Sakai T, Yamaguchi S, An SH, Abe M, Wakisaka S, Lee KY, Egusa H, Imazato S. 2011. Hydrogel-based biomimetic environment for in vitro modulation of branching morphogenesis. Biomaterials 32:6754-6763.

Mohan N, Nair PD, Tabata Y. 2010. Growth factor-mediated effects on chondrogenic differentiation of mesenchymal stem cells in 3D semi-IPN poly(vinyl alcohol)-poly(caprolactone) scaffolds. J Biomed Mater Res A 94A:146-159.

Morgan AW, Roskov KE, Lin-Gibson S, Kaplan DL, Becker ML, Simon CG. 2008. Characterization and optimization of RGD-containing silk blends to support osteoblastic differentiation. Biomaterials 29:2556-2563.

Moura RM, de Queiroz AAA. 2011. Dendronized polyaniline nanotubes for cardiac tissue engineering. Artif Organs 35:471-477.

Moutos FT, Estes BT, Guilak F. 2010. Multifunctional hybrid three-dimensionally woven scaffolds for cartilage tissue engineering. Macromol Biosci 10:1355-1364.

Murphy WL, Hsiong S, Richardson TP, Simmons CA, Mooney DJ. 2005. Effects of a bone-like mineral film on phenotype of adult human mesen- chymal stem cells in vitro. Biomaterials 26:303-310.

Murphy WL, Peters MC, Kohn DH, Mooney DJ. 2000. Sustained release of vascular endothelial growth factor from mineralized poly(lactide-co-glycolide) scaffolds for tissue engineering. Biomaterials 21:2521-2527.

Naing MW, Williams DJ. 2011. Threedimensional culture and bioreactors for cellular therapies. Cytotherapy 13:391-399.

Natarajan A, Chun CJ, Hickman JJ, Molnar P. 2008. Growth and electrophysiological properties of rat embryonic cardiomyocytes on hydroxyland carboxyl-modified surfaces. J Biomat Sci Polym Ed 19:1319-1331.

Nisbet DR, Forsythe JS, Shen W, Finkelstein DI, Horne MK. 2009. Review paper: a review of the cellular response on electrospun nanofibers for tissue engineering. J Biomater Appl 24:7-29.

Pan LJ, Ren YJ, Cui FZ, Xu QY. 2009. Viability and differentiation of neural precursors on hyaluronic acid hydrogel scaffold. J Neurosci Res 87:3207-3220.

Pant HR, Neupane MP, Pant B, Panthi G, Oh HJ, Lee MH, Kim HY. 2011. Fabrication of highly porous poly (epsilon-caprolactone) fibers for novel tissue scaffold via water-bath electrospinning. Colloid Surface B 88:587-592.

Park JS, Chu JS, Tsou AD, Diop R, Tang ZY, Wang AJ, Li S. 2011a. The effect of matrix stiffness on the differentiation of mesenchymal stem cells in response to TGF-beta. Biomaterials 32:3921-3930.

Park J, Lim E, Back S, Na H, Park Y, Sun K. 2010. Nerve regeneration following spinal cord injury using matrix metalloproteinase-sensitive, hyaluronic acid-based biomimetic hydrogel scaffold containing brain-derived neurotrophic factor. J Biomed Mater Res A 93A:1091-1099.

Park JS, Yang HN, Woo DG, Jeon SY, Do HJ, Lim HY, Kim JH, Park KH. 2011b. Chondrogenesis of human mesenchymal stem cells mediated by the combination of SOX trio SOX5, 6 , and 9 genes complexed with PEImodified PLGA nanoparticles. Biomaterials 32:3679-3688.

Pei Y, Zhang LN, Wang HY, Zhang XZ, $\mathrm{Xu}$ M. 2011. Supermolecular structure and properties of cellulose/gelatin composite films. Acta Polym Sin 9:1098-1104.

Pek YS, Wan ACA, Ying JY. 2010. The effect of matrix stiffness on mesenchymal stem cell differentiation in a 3D thixotropic gel. Biomaterials 31:385-391.

Petrie TA, Raynor JE, Reyes CD, Burns KL, Collard DM, Garcia AJ. 2008. The effect of integrin-specific bioactive coatings on tissue healing and implant osseointegration. Biomaterials 29:2849-2857.
Peyton SR, Kim PD, Ghajar CM, Seliktar D, Putnam AJ. 2008. The effects of matrix stiffness and RhoA on the phenotypic plasticity of smooth muscle cells in a 3-D biosynthetic hydrogel system. Biomaterials 29: 2597-2607.

Phillips JE, Burns KL, Le Doux JM, Guldberg RE, Garcia AJ. 2008. Engineering graded tissue interfaces. Proc Natl Acad Sci USA 105:1217012175.

Ponader S, Vairaktaris E, Heinl P, Wilmowsky CV, Rottmair A, Koerner C, Singer RF, Holst S, Schlegel KA, Neukarn FW, Nkenke E. 2008. Effects of topographical surface modifications of electron beam melted Ti-6Al-4V titanium on human fetal osteoblasts. J Biomed Mater Res A 84A:11111119.

Qiu Y, Park K. 2001. Environment-sensitive hydrogels for drug delivery. Adv Drug Deliv Rev 53:321-339.

Ragetly G, Griffon DJ, Chung YS. 2010. The effect of type II collagen coating of chitosan fibrous scaffolds on mesenchymal stem cell adhesion and chondrogenesis. Acta Biomater 6: 3988-3997.

Ranella A, Barberoglou M, Bakogianni S, Fotakis C, Stratakis E. 2010. Tuning cell adhesion by controlling the roughness and wettability of 3D micro/nano silicon structures. Acta Biomater 6:2711-2720.

Re'em T, Tsur-Gang O, Cohen S. 2010. The effect of immobilized RGD peptide in macroporous alginate scaffolds on TGF beta 1-induced chondrogenesis of human mesenchymal stem cells. Biomaterials 31:6746-6755.

Ren YJ, Zhou ZY, Cui FZ. 2009. Hyaluronic acid/polylysine hydrogel as a transfer system for transplantation of neural stem cells. ] Bioact Compat Polym 24:56-62.

Reyes $C D$, Petrie TA, Burns $K L$, Schwartz Z, Garcia AJ. 2007. Biomolecular surface coating to enhance orthopaedic tissue healing and integration. Biomaterials 28:3228-3235.

Richardson TP, Murphy WL, Mooney DJ. 2001. Polymeric delivery of proteins and plasmid DNA for tissue engineering and gene therapy. Crit Rev Eukaryot Gene Expr 11:47-58.

Rnjak-Kovacina J, Wise SG, Li Z, Maitz PKM, Young CJ, Wang YW, Weiss AS. 2011. Tailoring the porosity and pore size of electrospun synthetic human elastin scaffolds for dermal tissue engineering. Biomaterials 32:67296736.

Robinson L, Isaksson J, Robinson ND, Berggren M. 2006. Electrochemical control of surface wettability of poly(3-alkylthiophenes). Surface Sci 600:L148-L152.

Rocha PM, Santo VE, Gomes ME, Reis RL, Mano JF. 2011. Encapsulation of adipose-derived stem cells and transforming growth factor-beta 1 in carrageenan-based hydrogels for 
cartilage tissue engineering. ] Bioact Compat Polym 26:493-507.

Roether JA, Boccaccini AR, Hench LL, Maquet V, Gautier S, Jerome R. 2002. Development and in vitro characterisation of novel bioresorbable and bioactive composite materials based on polylactide foams and Bioglass ( $R$ ) for tissue engineering applications. Biomaterials 23: 3871-3878.

Rossello RA, Wang Z, Kizana E, Krebsbach PH, Kohn DH. 2009. Connexin 43 as a signaling platform for increasing the volume and spatial distribution of regenerated tissue. Proc Natl Acad Sci USA 106:1321913224.

Saha K, Keung AJ, Irwin EF, Li Y, Little L, Schaffer DV, Healy KE. 2008. Substrate modulus directs neural stem cell behavior. Biophys J 95:44264438.

Sa-Lima H, Caridade SG, Mano JF, Reis RL. 2010. Stimuli-responsive chitosan-starch injectable hydrogels combined with encapsulated adiposederived stromal cells for articular cartilage regeneration. Soft Matter 6:5184-5195.

Sa-Lima H, Tuzlakoglu K, Mano JF, Reis RL. 2011. Thermoresponsive poly(N-isopropylacrylamide)-g-methylcellulose hydrogel as a threedimensional extracellular matrix for cartilage-engineered applications. J Biomed Mater Res A 98A:596-603.

Schek RM, Taboas JM, Segvich SJ, Hollister SJ, Krebsbach PH. 2004. Engineered osteochondral grafts using biphasic composite solid freeform fabricated scaffolds. Tissue Eng 10:1376-1385.

Schrader J, Gordon-Walker TT, Aucott $R L$, van Deemter $M$, Quaas $A$, Walsh S, Benten D, Forbes SJ, Wells RG, Iredale JP. 2011. Matrix stiffness modulates proliferation, chemotherapeutic response, and dormancy in hepatocellular carcinoma cells. Hepatology 53:1192-1205

Segvich S, Biswas S, Becker U, Kohn $\mathrm{DH}$. 2009a. Identification of peptides with targeted adhesion to bone-like mineral via phage display and computational modeling. Cells Tissues Organs 189:245-251.

Segvich S, Kohn DH. 2009. Phage Display as a Strategy for Designing Organic/Inorganic Biomaterials. Biological Interactions on Materials Surfaces: Understanding and Controlling Protein, Cell, and Tissue Responses. New York: Springer. p 115-132.

Segvich SJ, Smith HC, Kohn DH. 2009b. The adsorption of preferential binding peptides to apatite-based materials. Biomaterials 30:1287-1298.

Segvich S, Smith HC, Luong LN, Kohn DH. 2008. Uniform deposition of protein incorporated mineral layer on three-dimensional porous polymer scaffolds. J Biomed Mater Res B 84B:340-349.
Shanbhag MS, Lathia JD, Mughal MR, Francis NL, Pashos N, Mattson MP, Wheatley MA. 2010. Neural progenitor cells grown on hydrogel surfaces respond to the product of the transgene of encapsulated genetically engineered fibroblasts. Biomacromolecules 11:2936-2943.

Shapira-Schweitzer K, Habib M, Gepstein L, Seliktar D. 2009. A photopolymerizable hydrogel for 3-D culture of human embryonic stem cell-derived cardiomyocytes and rat neonatal cardiac cells. J Mol Cell Cardiol 46:213-224.

Sharma B, Williams CG, Khan M, Manson $P$, Elisseeff JH. 2007. In vivo chondrogenesis of mesenchymal stem cells in a photopolymerized hydrogel. Plast Reconstr Surg 119: 112-120.

Shin YM, Kim KS, Lim YM, Nho YC, Shin H. 2008. Modulation of spreading, proliferation, and differentiation of human mesenchymal stem cells on gelatinimmobilized poly(L-lactide-co-epsiloncaprolactone) substrates. Biomacromolecules 9:1772-1781.

Shin JH, Lee JW, Jung JH, Cho DW, Lim G. 2011. Evaluation of cell proliferation and differentiation on a poly(propylene fumarate) 3D scaffold treated with functional peptides. J Mater Sci 46:5282-5287.

Singh D, Tripathi A, Nayak V, Kumar A. 2011. Proliferation of chondrocytes on a 3-D modelled macroporous poly (hydroxyethyl methacrylate)-gelatin cryogel. J Biomat Sci Polym Ed 22:1733-1751.

Spiller KL, Holloway JL, Gribb ME, Lowman AM. 2011. Design of semidegradable hydrogels based on poly(vinyl alcohol) and poly(lacticco-glycolic acid) for cartilage tissue engineering. J Tissue Eng Regen Med 5:636-647.

Steinmetz NJ, Bryant SJ. 2011. The effects of intermittent dynamic loading on chondrogenic and osteogenic differentiation of human marrow stromal cells encapsulated in RGDmodified poly(ethylene glycol) hydrogels. Acta Biomater 7:3829-3840.

Subramanian A, Krishnan UM, Sethuraman S. 2009. Development of biomaterial scaffold for nerve tissue engineering: biomaterial mediated neural regeneration. ] Biomed Sci 16:108-119.

Taboas JM, Maddox RD, Krebsbach PH, Hollister SJ. 2003. Indirect solid free form fabrication of local and global porous, biomimetic and composite 3D polymer-ceramic scaffolds. Biomaterials 24:181-194.

Thonhoff JR, Lou DI, Jordan PM, Zhao X, Wu P. 2008. Compatibility of human fetal neural stem cells with hydrogel biomaterials in vitro. Brain Res 1187:42-51.

Thorp BH, Anderson I, Jakowlew SB. 1992. Transforming growth factorbeta-1, factor-beta-2 and factor- beta-3 in cartilage and bone-cells during endochondral ossification in the chick. Development 114:907911.

Tian WM, Zhang CL, Hou SP, Yu X, Cui $F Z$, Xu QY, Sheng SL, Cui H, Li HD. 2005. Hyaluronic acid hydrogel as Nogo-66 receptor antibody delivery system for the repairing of injured rat brain: in vitro. J Controlled Release 102:13-22.

Tobias CA, Dhoot NO, Wheatley MA, Tessler A, Murray M, Fischer I. 2001. Grafting of encapsulated BDNF-producing fibroblasts into the injured spinal cord without immune suppression in adult rats. J Neurotrauma 18:287-301.

Toh WS, Lee EH, Guo XM, Chan JKY, Yeow CH, Choo AB, Cao T. 2010. Cartilage repair using hyaluronan hydrogel-encapsulated human embryonic stem cell-derived chondrogenic cells. Biomaterials 31:6968-6980.

Tuszynski MH, Grill R, Jones LL, Brant A, Blesch A, Low K, Lacroix S, Lu P. 2003. NT-3 gene delivery elicits growth of chronically injured corticospinal axons and modestly improves functional deficits after chronic scar resection. Exp Neurol 181:47-56.

VandeVondele S, Voros J, Hubbell JA. 2003. RGD-grafted poly-I-lysine-graft(polyethylene glycol) copolymers block non-specific protein adsorption while promoting cell adhesion. Biotechnol Bioeng 82:784-790.

Vandrovcova M, Bacakova L. 2011. Adhesion, growth and differentiation of osteoblasts on surface-modified materials developed for bone implants. Physiol Res 60:403-417.

Venugopal JR, Low S, Choon AT, Kumar AB, Ramakrishna S. 2008. Nanobioengineered electrospun composite nanofibers and osteoblasts for bone regeneration. Artif Organs 32:388-397.

Venugopal J, Prabhakaran MP, Zhang YZ, Low S, Choon AT, Ramakrishna S. 2010. Biomimetic hydroxyapatitecontaining composite nanofibrous substrates for bone tissue engineering. Philos Trans R Soc A Math Phys Eng Sci 368:2065-2081.

Vergroesen PPA, Kroeze RJ, Helder MN, Smit TH. 2011. The Use of poly(L-lactide-co-caprolactone) as a scaffold for adipose stem cells in bone tissue engineering: application in a spinal fusion model. Macromol Biosci 11:722-730.

Villa-Diaz LG, Nandivada H, Ding J, Nogueira-De-Souza NC, Krebsbach PH, O'Shea KS, Lahann J, Smith GD. 2010. Synthetic polymer coatings for long-term growth of human embryonic stem cells. Nat Biotechnol 28:581-583.

Wall ST, Yeh C-C, Tu RYK, Mann MJ, Healy KE. 2010. Biomimetic matrices for myocardial stabilization and stem cell transplantation. J Biomed Mater Res A 95A:1055-1066. 
Wang LS, Boulaire J, Chan PPY, Chung JE, Kurisawa M. 2010a. The role of stiffness of gelatin-hydroxyphenylpropionic acid hydrogels formed by enzyme-mediated crosslinking on the differentiation of human mesenchymal stem cell. Biomaterials 31:86088616.

Wang LS, Chung JE, Chan PPY, Kurisawa M. 2010b. Injectable biodegradable hydrogels with tunable mechanical properties for the stimulation of neurogenesic differentiation of human mesenchymal stem cells in 3D culture. Biomaterials 31:1148-1157.

Weaver VM, Petersen OW, Wang $F$, Larabell CA, Briand P, Damsky C, Bissell MJ. 1997. Reversion of the malignant phenotype of human breast cells in three-dimensional culture and in vivo by integrin blocking antibodies. J Cell Biol 137:231-245.

Wei Y, Li BS, Fu CK, Qi HX. 2010. Electroactive conducting polymers for biomedical applications. Acta Polym Sin 12:1399-1405.

Wei $Y$, Zhang $X H$, Song $Y$, Han $B$, Hu $X Y$, Wang $X Z$, Lin $Y H$, Deng $X L$. 2011. Magnetic biodegradable $\mathrm{Fe}(3) \mathrm{O}(4) / \mathrm{CS} / \mathrm{PVA}$ nanofibrous membranes for bone regeneration. Biomed Mater 6:055008.

Wojtowicz AM, Shekaran A, Oest ME, Dupont KM, Templeman KL, Hutmacher DW, Guldberg RE, Garcia AJ. 2010. Coating of biomaterial scaffolds with the collagen-mimetic peptide GFOGER for bone defect repair. Biomaterials 31:2574-2582.

Wu SC, Chang WH, Dong GC, Chen KY, Chen YS, Yao CH. 2011. Cell adhesion and proliferation enhancement by gelatin nanofiber scaffolds. J Bioact Compat Polym 26:565-577.

Xynos ID, Edgar AJ, Buttery LDK, Hench LL, Polak JM. 2000a. Ionic products of bioactive glass dissolu- tion increase proliferation of human osteoblasts and induce insulin-like growth factor II mRNA expression and protein synthesis. Biochem Biophys Res Commun 276:461-465.

Xynos ID, Hukkanen MVJ, Batten JJ, Buttery LD, Hench LL, Polak JM. 2000b. Bioglass (R) 4555 stimulates osteoblast turnover and enhances bone formation in vitro: implications and applications for bone tissue engineering. Calcif Tissue Int 67:321329.

Yang F, Murugan R, Wang S, Ramakrishna S. 2005. Electrospinning of nano/micro scale poly(L-lactic acid) aligned fibers and their potential in neural tissue engineering. Biomaterials 26:2603-2610.

Yang XBB, Webb D, Blaker J, Boccaccini $A R$, Maquet $V$, Cooper $C$, Oreffo ROC. 2006. Evaluation of human bone marrow stromal cell growth on biodegradable polymer/Bioglass (R) composites. Biochem Biophys Res Commun 342:1098-1107.

Ye ZY, Zhou Y, Cai HB, Tan WS. 2011. Myocardial regeneration: Roles of stem cells and hydrogels. Adv Drug Deliv Rev 63:688-697.

Yokoyama S, Fukuda N, Saito S, Kawano T, Li Y, Mugishima H. 2006. Human umbilical cord blood cells improve cardiac function after myocardial infarction. Am J Cardiol 98:219M-219M.

You ML, Peng GF, Li JA, Ma P, Wang $\mathrm{ZH}$, Shu WL, Peng SW, Chen GQ. 2011. Chondrogenic differentiation of human bone marrow mesenchymal stem cells on polyhydroxyalkanoate (PHA) scaffolds coated with PHA granule binding protein PhaP fused with RGD peptide. Biomaterials 32:2305-2313.

$\mathrm{Yu}$ JS, Du KT, Fang QZ, Gu YP, Mihardja SS, Sievers RE, Wu JC, Lee
RJ. 2010. The use of human mesenchymal stem cells encapsulated in RGD modified alginate microspheres in the repair of myocardial infarction in the rat. Biomaterials 31:70127020.

Zhang NL, Molenda JA, Fournelle JH, Murphy WL, Sahai N. 2010b. Effects of pseudowollastonite (CaSiO(3)) bioceramic on in vitro activity of human mesenchymal stem cells. Biomaterials 31:7653-7665.

Zhang L, Stauffer WR, Jane EP, Sammak PJ, Cui XYT. 2010a. Enhanced differentiation of embryonic and neural stem cells to neuronal fates on laminin peptides doped polypyrrole. Macromol Biosci 10:1456-1464.

Zhang XZ, Wu DQ, Chu CC. 2004. Synthesis, characterization and controlled drug release of thermosensitive IPN-PNIPAAm hydrogels. Biomaterials 25:3793-3805.

Zhao L, Burguera EF, Xu HHK, Amin N, Ryou H, Arola DD. 2010. Fatigue and human umbilical cord stem cell seeding characteristics of calcium phosphate-chitosan-biodegradable fiber scaffolds. Biomaterials 31:840-847.

Zhao F, Grayson WL, Ma T, Bunnell B, Lu WW. 2006a. Effects of hydroxyapatite in 3-D chitosan-gelatin polymer network on human mesenchymal stem cell construct development. Biomaterials 27:1859-1867.

Zhao G, Zinger O, Schwartz Z, Wieland M, Landolt D, Boyan BD. 2006b. Osteoblast-like cells are sensitive to submicron-scale surface structure. Clin Oral Implan Res 17:258-264.

Zimmermann WH, Schneiderbanger K, Schubert $P$, Didie $M$, Munzel F, Heubach JF, Kostin S, Neuhuber WL, Eschenhagen T. 2002. Tissue engineering of a differentiated cardiac muscle construct. Circ Res 90:223230. 